\title{
Formalizing Clientelism in Kenya: \\ From Harambee to the Constituency Development Fund
}

\author{
Ken Ochieng' Opalo \\ Georgetown University
}

\begin{abstract}
:
Why does clientelism persist? What determines how politicians signal responsiveness to voters and exert effort towards fulfilling campaign promises? This article explores how state capacity, legislative institutional strength, and established ideas about what politicians can do structure the political market in legislative elections. The argument herein is that campaign promises must be credible to have any currency. Therefore, programmatic campaign promises are likely to be more credible in countries with strong states and legislatures, while clientelism predominates in weak states whose legislatures cannot compel the executive branch to implement legislators' campaign promises. Historical experience also matters in shaping shared expectations of what politicians can do and the feasible sets of credible campaign promises. I support these arguments with a historical institutionalist analysis of Kenya's Harambee Movement and the Constituency Development Fund (CDF), as well as evidence from a nationally representative survey. Findings corroborate the claim that clientelism persists when it is the most credible means of fulfilling campaign promises. This article also shows that rising costs can precipitate legislative reforms away from clientelism as happened with the creation of Kenya's CDF in 2003. Overall, this article increases our understanding of the origins and persistence of clientelism in low-income states and potential avenues for reform towards programmatic politics.
\end{abstract}

Keywords: Constituency Service, Legislative Politics, Historical Institutionalism, Constituency Development Fund, Kenya 


\section{Introduction:}

Why do clientelist electoral systems persist? What determines how politicians signal effort and responsiveness to voters? In electoral democracies, voters expect politicians to be responsive and to fulfill their campaign promises (Fenno, 1978; Barkan, 1979). However, despite these shared incentives, significant cross-country variation exists in the nature of the electoral relationship between voters and politicians. This is especially true regarding legislative politics. In some contexts, legislators strive to be responsive predominantly via indirect/institutional means. They enact programmatic policies and influence the behavior of the executive branch through oversight and the budget process (Ferejohn, 1974; Cox and McCubbins, 1993). In others, legislators signal responsiveness primarily via direct/informal constituency service and targeted benefits that may be characterized as clientelistic (Wantchekon, 2003; Stokes, 2005; Lindberg, 2010; Gadjanova, 2017; Opalo, 2019).

This article describes the evolution of clientelism amidst increasing institutionalization of politics in Kenya. ${ }^{1}$ Stylized accounts of political markets usually posit two ideal-type equilibria in which politicians maximize electoral support by signaling responsiveness either predominantly through programmatic policies (governed by rule-based public criteria for access) or clientelism (exchange of targeted benefits for votes). In reality, both modes of electoral exchange co-exist in most countries. This is because factors beyond the control of individual politicians and voters structure political markets. For instance, legislators' ability to win votes by enacting programmatic policies requires high levels of legislative strength as well as state fiscal and bureaucratic capacity. ${ }^{2}$

\footnotetext{
${ }^{1}$ See Hicken (2011), Stokes et al. (2013), Golden and Min (2012), and Nichter (2018) for reviews of clientelism and distributive politics.

${ }^{2}$ Weak bureaucracies distort political markets. For example, Williams (2017) and Dasgupta and Kapur (forthcoming) document the prevalence of incomplete projects in Ghana and bureaucratic overload in India, respectively.
} 
In the same vein, historical experiences may reinforce voters' and politicians' beliefs about the fixity of the nature of political markets. Therefore, the ability to credibly promise programmatic policymaking is not always available to legislators in states historically lacking in fiscal and bureaucratic capacity or strong legislatures that can effectively direct executive bureaucratic action through legislation. In such contexts, promises of clientelist targeting may be more credible.

The main argument herein is that clientelism persists in legislative electoral politics when it is the most credible means through which politicians can deliver on their campaign promises. Given the incentives for credit-claiming, legislators signal effort and responsiveness in ways that are legible to voters (by exerting effort in conformity with voters' expectations). Legislators that deviate from expected ways of signaling effort are likely to be perceived as "deviant" types and punished at the ballot. The state's ability to provide essential public goods and services (state capacity) and the institutional strength of the legislature (ability to influence executive agencies) determine legislative incumbents' feasible modes of credibly signaling effort. Legislators in countries with strong legislatures and capable states are more likely to signal responsiveness predominantly through programmatic policies, while their counterparts serving in weak legislatures and whose states lack fiscal and bureaucratic capacity are more likely to rely on targeted clientelism.

Legislative electoral politics present a unique opportunity to study the trade-off between clientelism and programmatic policies among politicians, while also highlighting how institutional variables (both formal and informal) shape individual-level voting behavior. Unlike presidents who sit atop bureaucracies that can directly implement campaign promises, legislators can only do so indirectly through laws and reliance on (executive) bureaucratic implementation. Furthermore, legislatures do not always have the political power to compel executive bureaucracies to action. In 
many countries weak legislatures exist under the shadow of relatively more powerful executives. The fact that legislators perform both formal (potentially programmatic) functions such as lawmaking and oversight, and informal functions in the form of constituency service makes it possible to observe which functions both voters and legislators prioritize in the political marketplace, conditional on structural background conditions.

To understand why clientelism persists in legislative electoral politics, I evaluate material evidence from Kenya using a historical institutionalist approach (Mahoney and Thelen, 2010). First, I argue that clientelism persists in Kenya's legislative elections due to the weight of historical experience with a weak legislature, gaps in state bureaucratic and fiscal capacity that fueled a reliance on community self-help in funding local development projects (the Harambee Movement), and candidate-centric politics in the absence of strong party machines. In this context, the Harambee Movement emerged as an informal fiscal and redistributive institution through which aspiring politicians showcased their ability to initiate local development projects using private funds. ${ }^{3}$ Second, I describe how in 2003 legislators created the state-funded Constituency Development Fund (CDF) to formalize incumbents' contribution to local development projects, a significant proportion of which was previously funded through Harambees.

Official data on over 40,000 projects from the Constituency Development Fund (CDF), a nationally representative survey, and qualitative analysis of the emergence of CDF out of Kenya's Harambee (community self-help) Movement support this argument. ${ }^{4}$ Survey respondents put significantly more emphasis on legislators' direct constituency service than their formal

\footnotetext{
${ }^{3}$ See Bagaka (2010).

${ }^{4}$ After the original CDF Act (2003) was declared unconstitutional for granting parliament executive powers to directly implement legislation, the National Government Constituency Development Fund Act (2015) made the CDF compliant with the principle of separation of powers and renamed it the National Government Constituency Development Fund (NG-CDF). For simplicity, this article refers to the fund as CDF.
} 
constitutional functions; CDF projects match respondents' sectoral priorities; and qualitative evidence shows that CDF projects mirror historical patterns of sectoral allocations over decades of clientelism under the Harambee Movement. The Harambee Movement emerged in the 1960s as a government strategy to manage popular demand for development projects in the face of fiscal and bureaucratic capacity constraints. Over time, Harambees became the predominant means of signaling effort towards "development" by Kenyan politicians..$^{5}$ Importantly, one of the reasons legislators introduced the CDF in 2003 was to address rising Harambee costs. ${ }^{6}$

Kenya is an interesting case because it presents an example of a massive clientelistic system that at one time generated $12 \%$ of gross capital formation and which later precipitated legislative reforms due to rising costs and corruption. The CDF Act was designed to replace the largely clientelistic Harambee Movement with a formal process of delivering benefits to constituents $(\mathrm{CDF})$. The importance of understanding the historical evolution of clientelism in Kenya is threefold. First, clientelism is a critical part of political development. Many contemporary countries in which programmatic politics predominate have recent clientelistic roots that grew in tandem with competitive politics (Ben-Dor, 1974; Cox, 1987). Second, countries usually emerge out of clientelism not by completely uprooting the practice, but through formalization and/or gradual legitimation of clientelistic practices (Huckshorn, 1985) - not unlike Kenya's CDF. Finally, this paper has implications for democracy promotion efforts that seek to end clientelistic

\footnotetext{
${ }^{5}$ Here, "development" denotes a range of issue areas including but not limited to education, health, agriculture, security, roads, and access to water.

${ }^{6}$ The rising cost of Harambees impacted both politicians and voters alike. Increased corruption helped fund politicians (Transparency International, 2001; Waiguru, 2006). But voters suffered, too, as Harambees came with social obligations to contribute. A legislator observed that "we have been utilising the Harambee Movement, but as things stand now, the people at the grassroots level have been so outstretched that whenever we plan to build a primary school, they have to do Harambees repeatedly for many years before they build four classrooms." See Official Report, Kenya National Assembly, October 16, 2003 Col. 3128
} 
politics. Such efforts are only likely to succeed if accompanied by improvements in state capacity and institutional reforms that increase the credibility of programmatic campaign promises.

By employing a historical institutionalist approach that links the persistence of clientelism to institutional variables that define the political marketplace and influence voters' expectations, this paper synthesizes and contributes to different strands of literature, including works on constituency influence (Fenno, 1978; Barkan, 1979), state capacity and policy implementation (Williams, 2017; Dasgupta and Kapur, forthcoming), the politics of attribution and citizen demands (Calvo and Murillo, 2004; Lindberg, 2010; Kruks-Wisner, 2018; Tromborg and Schwindt-Bayer, 2018; Opalo, 2020a), and clientelism, patronage, and distributive politics (Wantchekon, 2003; Hicken, 2011; Stokes et al., 2013; Golden and Min, 2012; Bussell, 2019).

\section{Conceptualizing the Politics of Clientelism}

Politicians win elections based on promises and proven performance. ${ }^{7}$ In order to have the desired effect, campaign promises must be credible (Aragonés, Palfrey and Postlewaite, 2007) and related performance easily observable and attributable (Mani and Mukand, 2007). The credibility of campaign promises is driven by a combination of citizens' demands and politicians' capabilities. The nature and intensity of citizens' demands may be driven by their sense of political efficacy, experience with politicians, or established norms about "what politicians do." Voters do not always optimally calibrate their expectations and may demand more or less than political systems are able to deliver. On their part politicians are incentivized to make promises that are legible to voters, and which yield easily visible and attributable outcomes. To be credible, the same promises must

\footnotetext{
${ }^{7}$ Singer and Carlin (2013) show that prospective voting dominates early in the election cycle, with voters switching to performance based retrospective voting as incumbents accumulate records.
} 
reflect a shared understanding of what politicians are typically able to do. Implausible campaign promises get heavily discounted.

\subsection{When do Voters in Legislative Elections Prefer Clientelism?}

Voters in legislative elections are more likely to prefer clientelism when promises of targeted benefits are significantly more credible than programmatic policies. Legislative elections provide ideal conditions for understanding this dynamic. Assume that there are three stylized predominant modes through which incumbent legislators may exert effort, with each channel having implications for efficacious policy implementation and attribution. They can enact programmatic policies and diligently ensure their implementation by the executive branch (A); use party machines as platforms for providing public goods and services (B); or directly meet constituents' demands (C). In a high-capacity state in which executive agencies respond to legislative policy directives and oversight, channel $\mathrm{A}$ is likely to emerge as the predominant mode through which legislators meet voters' demands. In weaker states with organizationally strong political parties, service provision through party machines (B) may predominate. Finally, in contexts where both states and parties are weak, politicians may resort to direct provision of constituency service (C). ${ }^{8}$

Over time, the predominant mode of signaling effort defines the contours of credibility of campaign promises. Programmatic campaign promises are less likely to be credible in states with weak (legislative) institutions and which are lacking in fiscal and bureaucratic capacity. Legislators' inability to compel executive agencies to action through legislation and oversight may

\footnotetext{
${ }^{8}$ As Hicken (2011) observes, it is possible for programmatic and clientelistic forms of exchange to coexist in the same political market. The idea here is one of predominance - hence the distinction between programmatic and clientelistic political systems.
} 
prompt legislators to look for alternative (often direct/informal) means of meeting constituents' needs. If party machines exist, legislators are likely to resort to promises that are deliverable through party networks. In contexts where both parties and states are weak and have limited reach outside of capitals - like in many low-income countries - legislators may be forced to take matters in their own hands and directly provide attributable benefits to their constituents. ${ }^{9}$

While politicians may prefer to rely on any of the three channels of fulfilling their campaign promises, the preponderance of any given channel is likely to be dictated by conditions that are not easily manipulatable by either politicians or voters. Building state capacity, party machines, and strong legislatures take time. Therefore, the established patterns of signaling effort may not always be optimal for either voters or politicians. For example, the empirical record shows that while legislators in high-capacity states with strong legislatures have incumbency advantage, their counterparts in low-capacity states with weak legislatures face an incumbency disadvantage (Ariga 2010; Uppal, 2009; Opalo, 2019). In the former states, programmatic policies predominate the political marketplace (Morgan, 2013; MacDonald and McGrath, 2016), while clientelism predominates in the latter category of states (Wantchekon, 2003; Hicken, 2011). ${ }^{10}$

A priori it might seem that the predominance of clientelism in many low-income states provides opportunities for candidates in legislative elections to build a dependable personal vote. However, politics in low-income states is often characterized by "endemic voter discontent" because voters' demands typically go unmet due to low state capacity and fiscal constraints (Molina, 2001, p. 428). In these contexts, campaign promises of technocratic programmatic policies may not be credible as they would require visibly absent high levels of state capacity.

\footnotetext{
${ }^{9}$ Lindberg (2010) documents similar dynamics in Ghana from the perspective of legislators. Afrobarometer data from 20 African countries corroborate these findings (See Figure A8 in Appendix B).

${ }^{10}$ As an intermediate category, party machines can operate either predominantly along programmatic (even in the case of club goods) or clientelistic lines depending on a given country's political culture.
} 
Thus, voters and politicians remain stuck in a suboptimal electoral equilibrium marked by clientelistic candidate-centric politics and high levels of turnover. ${ }^{11}$

\subsection{Clientelism and Political Change}

While it is hard to unilaterally change the features of political markets outlined above, it is not impossible - as is evidenced by sweeping reforms in countries in which clientelism and patronage were replaced with programmatic politics (Ben-Dor, 1974; Cox, 1987). Catalysts for change may include political shocks like major corruption scandals, the collapse of a clientelistic regime, economic crises, or perceived rising costs of clientelism. It is also possible for countries experiencing institutional decay to "regress" from having predominantly programmatic politics to a political marketplace dominated by clientelism.

However, changes from the predominance of one mode of electoral exchange to another is seldom completely discontinuous. This is because, beyond exchanging benefits for votes, clientelistic politics typically encompasses broadly understood social contracts, informal institutions, and shared moral economies of politics (Cheeseman, Lynch, and Willis, 2021). Therefore, change mirrors institutional evolution whereby new structures and expectations are layered onto old mental models of how the world works (Thelen, 2004). For example, ending elite political capture may involve legislation formalizing the role of business in politics (La Raja, 2008). Overall, the need for continued legibility of politics and the persistence of mental models about "how politics works" create conditions for political market evolution rather than revolution.

\footnotetext{
11 These effects are negatively correlated with district magnitude, with candidate-centric politics likely to be highest in electoral systems with a district magnitude of one.
} 
The history of clientelistic politics in Kenya's legislative elections embodies these historical institutionalist dynamics. Beginning in the 1960s, the government explicitly acknowledged its lack of capacity to meet voters' demands for economic development. To fill this void, it promoted the Harambee Movement (Ngau, 1987). Soon after, Harambee contributions by politicians became the currency of legislative electoral politics (Barkan, 1976; Mbithi and Rasmusson, 1977; Barkan, 1979; Barkan and Okumu, 1980; Thomas, 1987; Opalo, 2019). Consequently, politics acquired a distinctively candidate-centric flavor that persists to this day.

The legacy of weak and transient political parties and first past the post electoral system in single member districts reinforced these dynamics. The reintroduction of multipartyism in 1992 heightened competition and raised the cost of Harambees for candidates in legislative elections. In 2003 legislators created the CDF to provide public funding for development projects that were previously funded by Harambees. The CDF was not designed to radically shift legislative electoral politics from a predominantly clientelistic system to a programmatic orientation. Instead, it merely formalized the financing and origination of projects, while preserving the basic elements of politicians' contribution to local development. Against the wishes of legislators, the executive initially wanted to house the CDF in the Office of the Vice President. ${ }^{12}$ However, legislators prevailed and established direct parliamentary control over the CDF and associated Constituency Development Fund Committees. ${ }^{13}$ The CDF can therefore be viewed as an incremental and not revolutionary attempt to formalize the clientelistic Harambee Movement. Institutionalized state funding, regulated project selection, reporting requirements, and parliamentary oversight were layered atop the clientelistic foundation that was the Harambee Movement.

\footnotetext{
${ }^{12}$ Government of Kenya, Official Report of the National Assembly, June 26, 2003, Col. 1666.

${ }^{13}$ Government of Kenya, Official Report of the National Assembly, November 27, 2003, Col. 4082; see also the Constituencies Development Fund Act, No. 10 (2003). Elsewhere in Africa, presidents neutralized the political potency of CDFs by retaining control of such slush funds within the executive (Tsubura, 2013).
} 


\section{Legislative Elections and Constituent Demands}

Kenya's CDF emerged as legislators' attempt to formalize certain aspects of the Harambee Movement amidst rising costs. The euphoria of independence in 1963 primed voters to expect rapid economic development and to view legislators primarily as links to central government resources (Barkan, 1979). However, the government lacked the fiscal and bureaucratic capacity to meet constituency-level demand for development projects (Bradshaw, 1993). In response, founding president Jomo Kenyatta championed "a development strategy based on the spirit of selfhelp" (Mwiria, 1990, p. 351), which became the Harambee Movement (Mbithi and Rasmusson, 1977). A political culture quickly bloomed around Harambees whereby politicians signaled effort through fundraising towards public goods and services in sectors as diverse as education, healthcare, agriculture, and general infrastructure development.

Since there was no government budget for Harambees, politicians dipped into their personal funds and/or fundraised from wealthy patrons. Furthermore, legislators could not simply compel executive agencies to implement projects in their constituencies on account of parliament's institutional weakness (Opalo, 2019). Under the circumstances, the president could make and unmake legislative political careers by rationing funds for Harambees. This was especially true under single party rule (1969-1992). The re-introduction of multiparty politics in 1992 and accompanying economic liberalization significantly liberalized the political market. Thereafter politicians did not have to rely on the ruling party's patronage networks and could access funds through growing commercial networks (Arriola, 2013).

Inevitably, the cost of Harambees and public corruption increased in tandem with multiparty competitiveness and liberalized access to funds (Transparency International, 2001; 
Waiguru, 2006). It is under these conditions that legislators created the CDF to serve the twin purposes of availing resources for development and to obviate the need for corruption to fund Harambees. ${ }^{14}$ One legislator succinctly summarized their intentions: "[w]e have said that Harambee which may have been started with a noble aim by our late founding father of this nation was abused very badly. It became a cancer in our country and we have to replace it with the Constituency Development Fund." 15 Overall, while the source of funds changed from private to public, project prioritization under $\mathrm{CDF}$ broadly mirrored patterns under the Harambee Movement. Because the CDF program did not eliminate Harambees, for good measure, legislators also banned politicians from taking part in Harambees eight months before elections. ${ }^{16}$ This ban, while affecting all candidates, disproportionately benefitted incumbents who could still implement and claim credit for CDF projects during the campaign season.

\subsection{The Harambee Movement}

As part of a clientelistic system, Harambees were not an optimal electoral strategy for Kenyan legislators. The fact that it became "the stuff of grassroots politics" (Barkan and Chege, 1989, p. 1) forced candidates in legislative elections to engage in public displays of wealth to signal their ability to deliver "development" to their constituents (Opalo, 2019). ${ }^{17}$ From the outset legislators complained about the financial burden of Harambees. In 1970 one observed: "I thought that Harambee was going to be additional to what the Government provides. It seems now that it is a

\footnotetext{
14 The reforms came on the heels of a report from the Task Force on Public Collections or "Harambees" headed Hon. Koigi Wamwere. See Kenya Government Gazette, No. 45 April 17, 2003

${ }^{15}$ Government of Kenya, Official Report of the National Assembly, April 17, 2003 Col. 1146.

16 See Republic of Kenya, Elections Act 2011, Article 26(1).

17 The system built on a pre-existing ethos of community self-help that was already common in Kenya for decades (Ngau, 1987).
} 
substitute and I think this is a wrong concept." 18 The same complaint was voiced three decades later. In 1999 a legislator complained that "once you become an MP you go bankrupt [...] Everything is done through Harambee! And every Harambee is on the MP!"19

These examples illustrate that targeted clientelism through Harambees did not favor incumbents. Yet they could not unilaterally adopt a programmatic approach that involved passing legislation and policies in Nairobi and overseeing their implementation by the executive through legislative oversight. The institutional (strong legislature) and bureaucratic (state fiscal capacity) basis for programmatic politics simply did not exist.

A standard Harambee cycle involved the identification of a project (either by the community or a local leader), acquiring a fundraising permit from the government, meetings to determine levels of community contributions, followed by community fundraising (Mbithi and Rasmusson, 1977; Winans and Haugerud, 1977; Ngau, 1987). In most instances, a local government official (e.g. Chief, District Officer or District Commissioner) would coordinate the collection of community contributions. ${ }^{20}$ Finally, the exercise would culminate in a public fundraising where wealthy patrons (including politicians from within and outside a constituency) would serve as "guests of honor" and individuals would publicly declare the value of their contributions. This provided politicians with the opportunity to try and outdo one another.

The Harambee Movement was not simply a manifestation of localized patronage politics directed by politicians. It was an important informal institution that structured distributive electoral politics and was the cornerstone of Kenya's grassroots developmental philosophy. The word Harambee is Kenya's national motto. While longitudinal data is unavailable, a 1974 survey found

\footnotetext{
${ }^{18}$ Government of of Kenya, Official Record of the National Assembly, June 26, 1970, Col. 1800.

${ }^{19}$ Government of Kenya, Official Record of the National Assembly, November 17, 1999, Vol. 2452 (translated from Kiswahili by author).

${ }^{20}$ Government of Kenya, Official Record of the National Assembly, March 13, 2003, Col. 451.
} 
that only $7 \%$ of Harambee initiators were politicians (Ngau, 1987, p. 528). Similarly, in a study of Coast and Western regions, Mbithi and Rasmusson (1977) find that only $11 \%$ and 5\% of project initiators were politicians, respectively.

From 1964 to 1984, about 37,300 Harambee projects were completed - the equivalent of $12 \%$ of the gross capital formation. Between 1963-1976, 40\% of the capital development in rural areas was attributable to Harambees (Berman, Cottrell and Ghai, 2009). At its peak, the system contributed upwards of 30\% of development expenditures. Between 1965 and 1984, on average, $90.1 \%$ of contributions came from private individuals, $5.7 \%$ from government assistance, and $4.2 \%$ from other sources (private firms, foreigners, and non-governmental organizations). ${ }^{21}$

In no sector was the Harambee Movement more important than in education. In the 1960s "the Harambee School Movement had assumed a distinctively political character as politicians, keen to ingratiate themselves with their constituents, began to play a principal role in the establishment of new schools and support of existing ones" (Mwiria, 1990, p. 350). A staggering $58 \%$ of all projects between 1964-1984 fell within the education sector. ${ }^{22}$ Between 1967-1972, $38 \%$ of total spending in education came from Harambees (Mbithi and Rasmusson, 1977). By 1989, 60.2\% of secondary schools were "Harambee Schools" (Bradshaw, 1993). ${ }^{23}$ Despite government allocation of upwards of $20 \%$ of the budget to education, citizen demands far outstripped the state's fiscal and bureaucratic capacity. Carrying this burden were candidates in legislative elections. For example, Simeon Nyachae, a civil servant and would be legislator, contributed more than Kshs. 6,000,000 (\$378,000 at the time) in 1986 spread across 202 primary schools (Leonard, 1991, p. 233).

\footnotetext{
${ }^{21}$ See Ngau (1987), p. 528.

${ }^{22}$ The health sector was a distant second at $10 \%$ (Berman, Cottrell and Ghai, 2009).

${ }^{23}$ World Bank Group (1989): The Financial Implications of Programmatic Changes in Kenya's Education System, 1990-2000.
} 
The politicization of Harambees intensified after 1992 as heightened electoral competitiveness forced politicians to attend ever more Harambees (Mwangi, 2008). For example, in the 1980 s, only $7 \%$ of Harambee contributions took place during election years. In the 1990s, contributions ahead of the competitive 1997 election made up $60 \%$ of all Harambees in the decade. Almost two thirds of the projects were in the education sector (Transparency International, 2001).

From the outset legislators expressed a preference for programmatic politics and implementation of development policy through the executive branch. In 1986 one asked: "Why can't we, Mr. Temporary Deputy Speaker, help our constituents through the ministry [of education]? Parents are taking part in too many Harambees. They are building classrooms through Harambees. They are buying books through Harambees. They are implementing all manner of projects through Harambees." 24 A decade later, another legislator posed a similar question: "Even where Harambee is conducted for a particular school, I have got more than 20 schools in Kikuyu Constituency, and I understand the president wants to come and conduct Harambee for Kirangari Secondary School, and he is welcome... But what about the other 19 secondary schools that we have in Kikuyu constituency? [...] I am trying to demonstrate that there is no way in which a Harambee can replace a funding policy for education." 25

These complaints exposed legislators' frustration with the personal financial cost of the Harambee Movement and its enduring influence on voters' expectations. Reflecting this concern, one member observed that " $[\mathrm{t}]$ here is a lot of blackmail and social pressure exerted $[\ldots]$ This is because every Hon. Member knows that when the elections are about to be held, every Harambee is compulsory" and concluded by terming Harambees as "endless, oppressive, exploitative fund

\footnotetext{
${ }^{24}$ Government of Kenya, Official Record of the National Assembly, April 30, 1986, Col. 464 (Translated from Kiswahili by author).

${ }^{25}$ Government of Kenya, Official Record of the National Assembly, October 31, 1996, Col. 2454.
} 
raising meetings every weekend." ${ }^{26}$ Yet given voters' expectations of "how politics works," legislators and aspiring candidates in legislative elections continued contributing to Harambees to signal their political viability. Elaborate programmatic policies were simply not credible.

\subsection{Formalizing Harambee: The Constituency Development Fund}

Fully aware of the history of the Harambee Movement, in 2003 Kenyan legislators designed the CDF to solve the twin problems of resource constraints and the lack of clear attribution for development projects. ${ }^{27}$ The 2003 CDF Act set aside $2.5 \%$ of the national government's share of ordinary tax revenue to be allocated to constituencies. ${ }^{28}$ Initially, $75 \%$ of the allocated funds are divided equally among Kenya's constituencies, with the remainder allocated based on poverty (constituency-level share of individuals living below the poverty line). Since 2015, all 290 constituencies have been receiving equal allocation. In the 2022/2021 fiscal year, the allocation was KES 137,088,879 (about US\$1,218,098.98) per constituency. Each year, constituencies can submit a minimum of 5 and maximum of 25 projects. ${ }^{29}$ In light of Kenya's devolved government, since 2015 CDF projects have been limited to sectors that fall under the delineated functions of the national government. ${ }^{30}$ Before 2015 there were no restrictions on sectoral spending. Allocations

\footnotetext{
${ }^{26}$ Republic of Kenya, Official Record of the National Assembly, March 13, 2003, Cols 451-452.

${ }^{27}$ Attribution is important under CDF. In supporting the CDF bill, one legislator noted that "[w] hen [a legislator] sees development taking place in his area, little credit goes to him if it is done by the Government or somebody else. When development does not take place in a constituency, all the blame is heaped on the elected Member of Parliament." See Official Report, Kenya National Assembly, October 16, 2003 Col. 3117. Harris (2021) observes that CDF followed "the modes of representation established over decades of patronage politics" (p. 30).

28 The original Constituencies Development Fund Act (2003) was replaced by the National Government Constituencies Development Act (2015) to make it compliant with constitutional separation of powers and the devolved system of government created in 2013.

${ }^{29}$ Government of Kenya, Constituencies Development Fund Act (2003).

${ }^{30}$ Constitutional devolution in Kenya delineates the functions of national and county governments (Opalo, 2020a). Transfers to the 47 counties are allocated by formula in a process that is distinct from the NG-CDF. The law restricts CDF expenditures to sectors aligned with national government functions. See Banful (2011) on the politics of formulabased subnational transfers.
} 
are cumulative, with unspent funds returned to constituencies' accounts. The Office of the Auditor General audits of all constituencies annually.

The CDF program reflects legislative finessing to maintain separation of powers while also granting legislators direct control over project choice and implementation in their constituencies. After courts declared the original 2003 Act unconstitutional for granting parliament executive powers,$^{31}$ a 2015 amendment domiciled the program in the executive branch while maintaining substantial legislative control. The resulting National Government Constituencies Development Fund (NG-CDF) is led by a board under the National Treasury and Planning ministry but reports directly to parliament. Furthermore, any appointments by the ministry and all activities of the board must be approved by the National Assembly, which also maintains a selected committee called the Constituencies Development Committee to oversee functions of the NG-CDF. The National Assembly has the powers to dismiss any board member for cause and approves the membership of all the $290 \mathrm{CDF}$ Committees (CDFCs) charged with identifying and managing operational aspects of project implementation. The NG-CDF constitutes CDFCs subject to parliament's approval. This institutional arrangement affords legislators effective control over CDFCs. According to one legislator, influence over CDFCs was important because "[t]here is no person in that constituency who has a greater stake in its development than the Hon. Member." 32 Ubiquitous billboards bearing legislators' names that dot schools, clinics, market centers, and other projects sites demonstrate the electoral importance of CDF projects. ${ }^{33}$

The growth of the CDF out of the Harambee Movement illustrates how countries may transition out of personalist clientelism into institutionalized forms of constituency service. While

\footnotetext{
31 "Court declares CDF Act invalid, gives govt 12 months to make amendments," Daily Nation, February 20, 2015

${ }^{32}$ Government of Kenya, Official Report of the National Assembly, November 27, 2003: Col. 4082.

${ }^{33}$ See Figure A2 in Appendix A.
} 
legislators have substantial influence over CDFCs, the formal processes involved minimize opportunities for personalist targeting that existed under the Harambee Movement. ${ }^{34}$ At the same time, there are several similarities between the Harambee Movement and CDF. For example, education projects consume the lion's share of allocations, with the Ministry of Education is the only line ministry (besides the "host," Treasury and Planning) that is represented on the NG-CDF board. In addition, the composition of CDFCs and the electoral motive ensure that project selection remains broadly aligned with voters' needs and expectations.

The timing of the introduction of CDF is also instructive. Recall that legislative strength conditions legislators' ability to influence executive branch agencies to implement campaign promises. It is not a coincidence that the type of CDF program that was passed in 2003 came after the 2002 presidential transition and a rebalancing of executive-legislative relations in favor of parliament (Opalo, 2019). No longer could the president resist legislators' attempt to free themselves from Harambee patronage networks controlled by the executive.

\section{Data and Empirics}

The above discussion outlines the structural conditions that shape the relationship between Kenyan legislators and their constituents. This section provides descriptive empirical support for the claim that Kenyan legislators' focus on constituency service and project prioritization under CDF match voters' expectations and reflect the historical legacy of the Harambee Movement. It also shows how legislators compensate for the fact that in Kenya, where formal functions (especially

\footnotetext{
${ }^{34}$ Harris and Posner (2019) find that CDF projects did not always target incumbents' supporters (conditional on political geography), and that "different local conditions generate different incentives and opportunities for the strategic allocation of political goods" (p. 137).
} 
legislation and oversight) seldom translate into visible and attributable government policies at the local level, legislators' stand little chance of winning elections by enacting programmatic policies. Instead, they rely on forms of direct constituency service that conform to voters' expectations.

To demonstrate that legislators are constrained in their choice of credible modes of signaling effort and responsiveness, I show that voters prioritize constituency service over formal legislative functions, and that this preference influences their vote choice. I then show that project choice under CDF conforms with voters' expectations and remains largely aligned with patterns that existed under the Harambee Movement. To this end I use two datasets - a nationally representative survey and official CDF data on more than 40,000 CDF projects.

\subsection{The Data}

The survey data used herein are from an IPSOS Omnibus survey conducted in April 2020 via the phone and targeted Kenyans of voting age (18 years and older). Table 1 summarizes key variables. Further description of the survey data is available in Appendix B. The average age of respondents in the survey is 37.8 years, $40 \%$ are female, and $32.6 \%$ reside in urban areas. The modal respondent has some secondary education. I operationalize political knowledge as awareness of the fact that health is a devolved function. ${ }^{35}$ Perhaps due to the novelty of devolution, $39.6 \%$ of respondents incorrectly attribute responsibility over health to the national government, a sign of low levels of political knowledge.

\footnotetext{
${ }^{35}$ See Opalo (2020a) on devolution and political knowledge in Kenya.
} 
Table 1: Summary Statistics

\begin{tabular}{lccccc}
\hline Variable & Mean & Std. Dev. & Min. & Max. & N \\
\hline Age & 37.806 & 12.79 & 18 & 98 & 1995 \\
Female & 0.399 & 0.49 & 0 & 1 & 2049 \\
Education & 4.814 & 2.079 & 1 & 11 & 3031 \\
Urban & 0.326 & 0.469 & 0 & 1 & 2049 \\
Political Knowledge & 0.396 & 0.489 & 0 & 1 & 2049 \\
Voted for Incumbent MP & 0.787 & 0.41 & 0 & 1 & 1996 \\
Would Reelect MP & 0.44 & 0.497 & 0 & 1 & 1937 \\
Soured on Incumbent MP & 0.372 & 0.484 & 0 & 1 & 2049 \\
MP Rating & 2.936 & 1.29 & 1 & 5 & 2049 \\
CDF Improved Conditions & 0.643 & 0.479 & 0 & 1 & 2006 \\
\hline
\end{tabular}

Like their counterparts in other low-income countries, Kenyan legislators operate in a context marked by high electoral turnover. While $78.7 \%$ of respondents reported having voted for their respective legislators in the 2017 election, only 44\% planned to reelect their legislators. In other words, $37.2 \%$ of respondents voted for their incumbent legislator but had since soured on their choice and did not plan to reelect them. These figures underscore the high turnover rates in Kenya's legislature (Opalo, 2019). On a scale of 1-5, the average rating of legislators among respondents is 2.9. Finally, $64.3 \%$ of respondents have a favorable view of CDF - a reflection of the popularity of projects implemented under the program.

To further understand CDF, I present data on more than 40,000 CDF projects implemented between 2003 and 2013 to illustrate the patterns of project investments at the constituency level. These data are from the NG-CDF Board. ${ }^{36}$ The objective here is to provide a simple descriptive account of the types of projects funded by legislators. As noted above, legislators have significant sway in the types of projects that get selected, especially in the years before the 2015 amendment of the original CDF Act - perhaps more so than under the Harambee Movement when most projects were initiated by communities.

\footnotetext{
${ }^{36}$ See here: https://ngcdf.go.ke/.I describe the CDF data in more detail in Appendix A.
} 


\subsection{Voters' Demands on Legislators I: Effort Allocation}

What do Kenyan voters expect of their legislators? This question is important for understanding the nature of the Kenyan political market and what kinds of campaign promises may be readily legible and credible to voters. The Kenyan constitution grants legislators the powers of oversight, representation, and legislation. ${ }^{37}$ Formal legislative functions are structured to facilitate programmatic modes of signaling effort and responsiveness. However, legislators' effort within formal channels may not always be visible and attributable to constituents. The potential mismatch between legislators' formal institutional functions and electoral realities underlines the importance of understanding voters' expectations of incumbents.

I find that $48.9 \%$ of respondents prefer legislative effort on constituency service and targeted benefits over formal legislative functions. This is shown in Figure 1, which summarizes respondents' top priorities when considering voting for legislators. ${ }^{38}$ A plurality of respondents in the survey assign top priority to either the utilization of CDF funds for development $(26.7 \%)$ or giving of money for constituents' needs $(22.2 \%)$. Barely half of respondents selected the formal legislative functions of representation (24.5\%), legislation (16.1\%), and oversight (10.4\%). Notice that representation as a category may include getting central government resources for constituency development, as was perceived during the Harambee era (Barkan, 1979). Overall, these results are suggestive of the fact that respondents place less weight on formal institutional legislative functions relative to direct constituency-level benefits provided by legislators.

\footnotetext{
${ }^{37}$ Constitution of the Republic of Kenya, Chapter Eight

38 The intention here was to force respondents to choose between institutional and non-institutional functions of legislators, and not specific issue areas (many of which can be addressed both through institutional and direct interventions by legislators).
} 
Figure 1: Top Priority in Evaluating Legislators

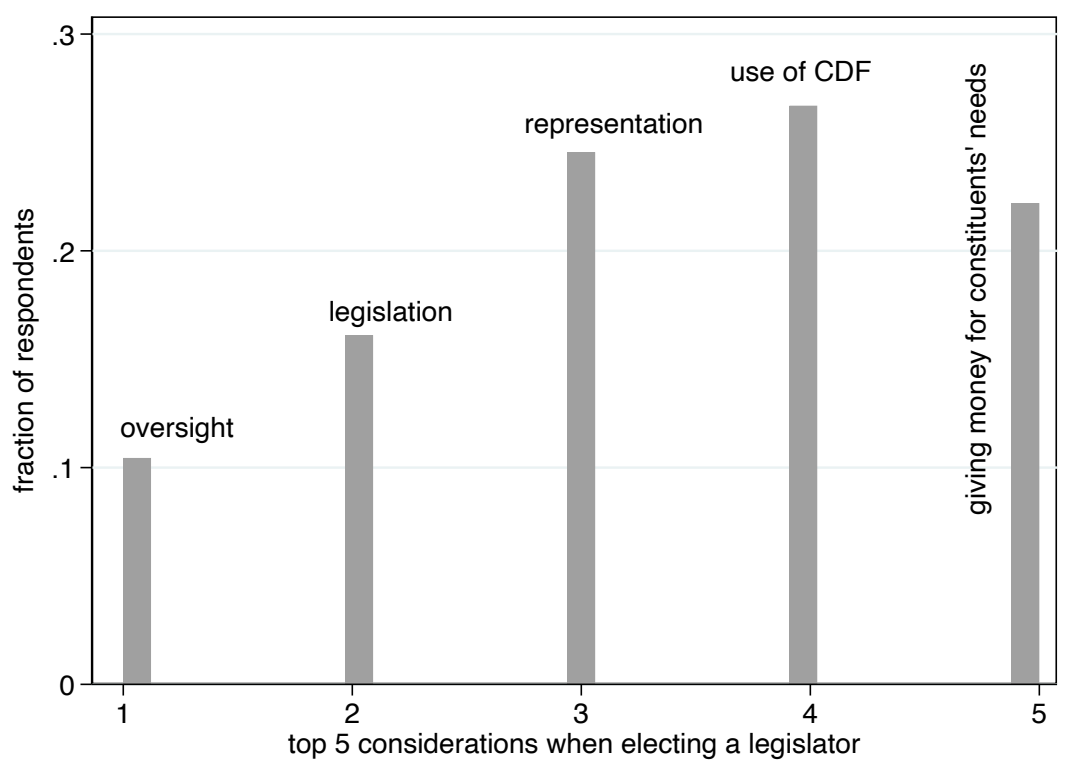

Notes: Figure indicates the distribution of respondents' stated top considerations when electing a legislator. Most respondents chose the use of CDF and targeted constituency-level benefits to be of a higher priority than the formal constitutional functions of oversight and legislation. Data from IPSOS.

Figure 2: Correlates of Prioritizing Formal Functions

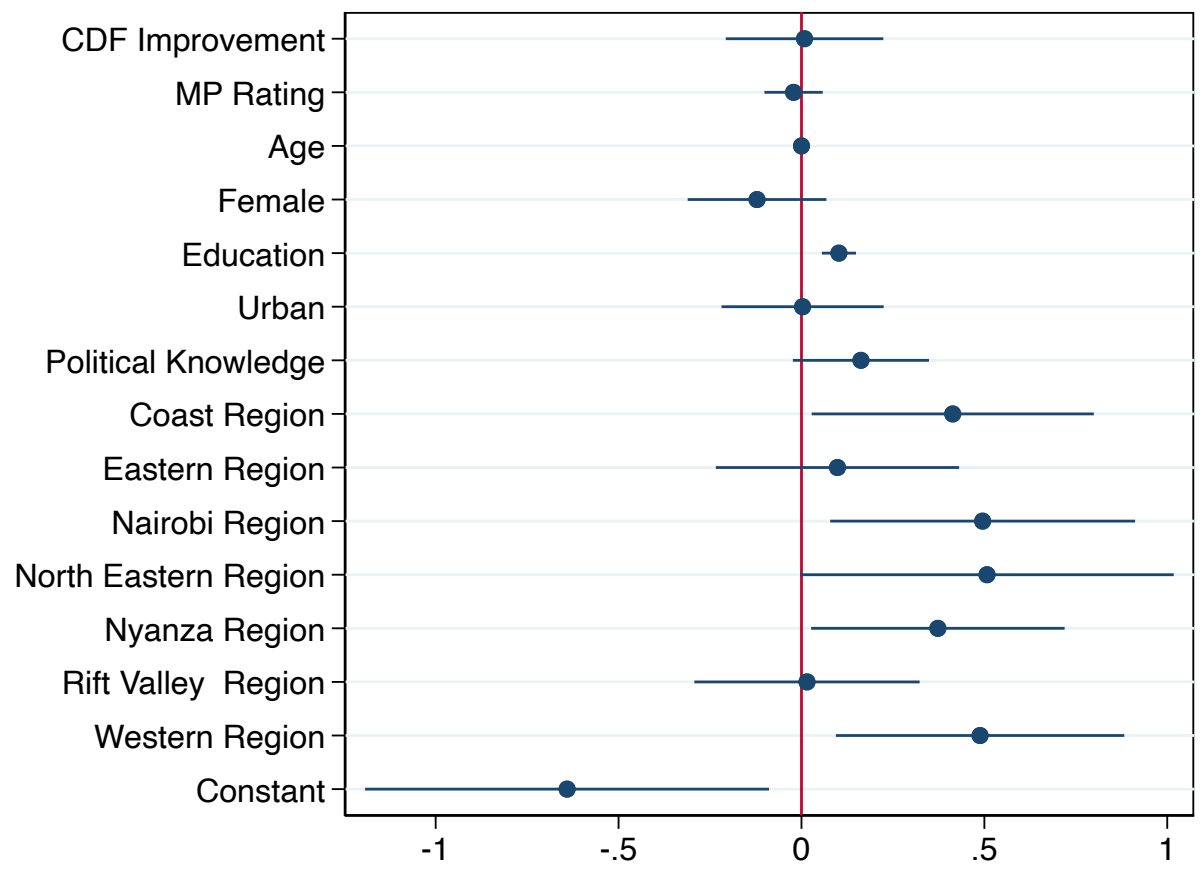

Notes: Figure indicates results from logistic regression on the correlates of prioritizing formal legislative functions when evaluating candidates. Education attainment is statistically correlated with prioritization of legislators' formal functions. There are also statistically significant regional variations in emphasis on formal functions. The referent region is Central Region. Data from IPSOS. 
Figure 2 shows the correlates of prioritizing formal legislative effort. Among individuallevel variables, only education attainment is positively correlated with self-reported consideration of formal legislative functions when evaluating candidates. The positive correlation between education attainment and emphasis on formal legislative functions may be due to information effects about how state institutions work. Another explanation might be that individuals with higher education have a lower demand for targeted constituency service in the form of CDF projects - perhaps because they primarily rely on private schools and hospitals. ${ }^{39}$

\subsection{Voters' Demands on Legislators II: Project Choice}

Next, I explore respondents' sectoral priorities and whether projects implemented under CDF match the public's priorities. If politicians seek to be legible and are indeed driven by voters' priorities, we should expect legislators' effort to mirror constituent demands with regards to choices of projects. Figure 3 shows the sectoral breakdown of respondents stated priorities. Like under the Harambee Movement, education and healthcare are the undisputed top priorities among respondents. Overall, 39.3\% indicated that education is their top priority sector, followed by healthcare $(30.9 \%)$, agriculture $(10.9 \%)$, water and sanitation $(10.2 \%)$, roads $(7.1 \%)$, and electricity $(1.6 \%)$.

Respondents' stated priorities are largely mirrored by actual investments under CDF. As shown in Figure 4, out of about 40,000 projects implemented between 2003 and 2010, education, water and sanitation, and healthcare, were the top three sectors by expenditure, respectively. Education alone accounted for more than $50 \%$ of total spending, mirroring patterns under the

\footnotetext{
${ }^{39}$ Calvo and Murillo (2004) show similar findings in Argentina.
} 
Harambee Movement. Available expenditure data from the 2013-14 fiscal year corroborate these findings. ${ }^{40}$ More than $55 \%$ of total projects are in the education sector, followed by the environment (much of which is tree planting in schools), water and sanitation, and healthcare projects.

Figure 3: Distribution of Reported Top Priority Sectors

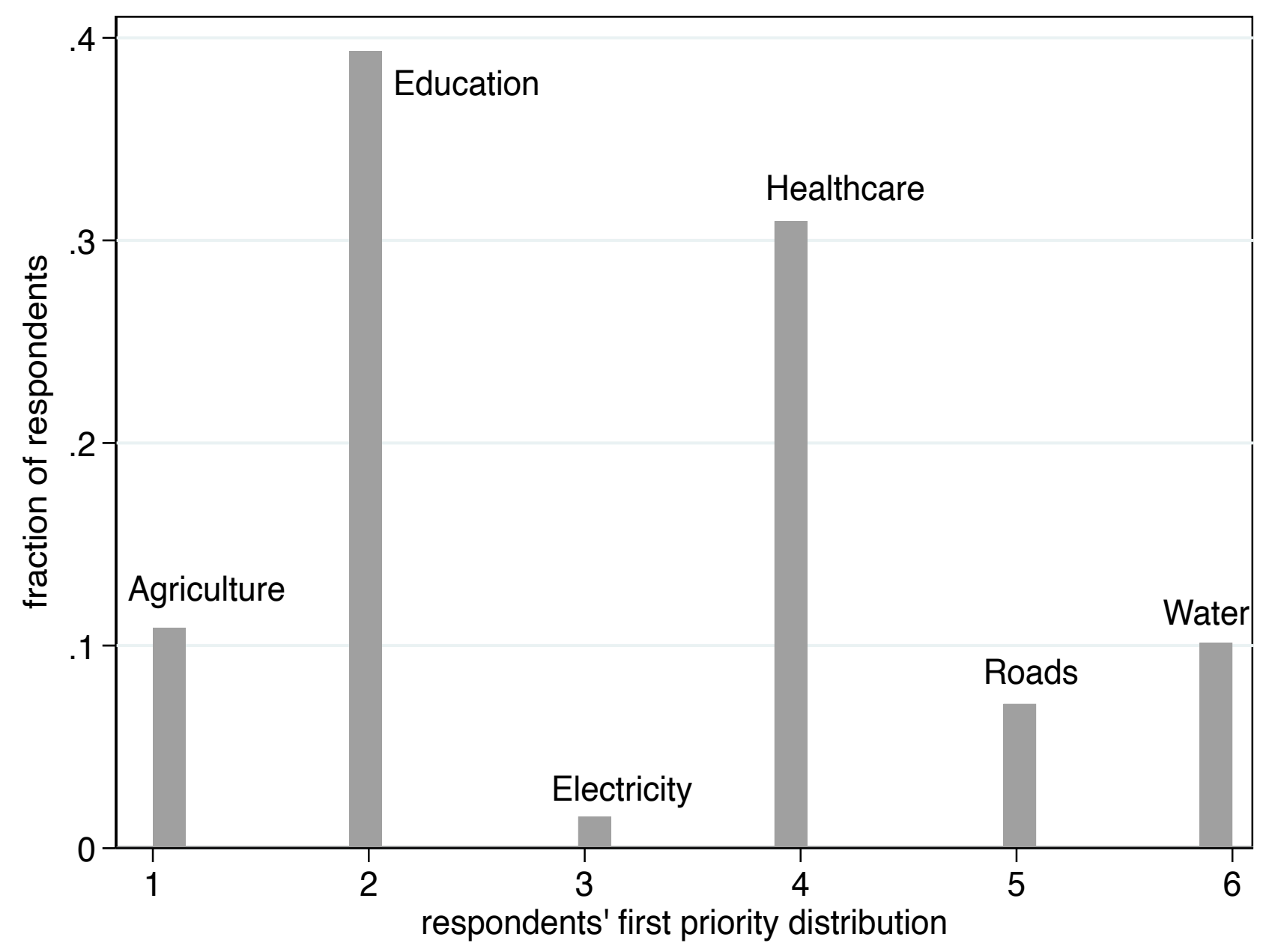

Notes: Figure shows the breakdown of respondent's preferred priority CDF sectors. The distribution mirrors both historical Harambee trends and actual CDF spending (see Figure 4). Data from IPSOS.

${ }^{40}$ In Appendix A, I provide a sample of recent data (FY 2020/2021) showing similar patterns. 
Figure 4: Distribution of CDF Expenditures by Sector

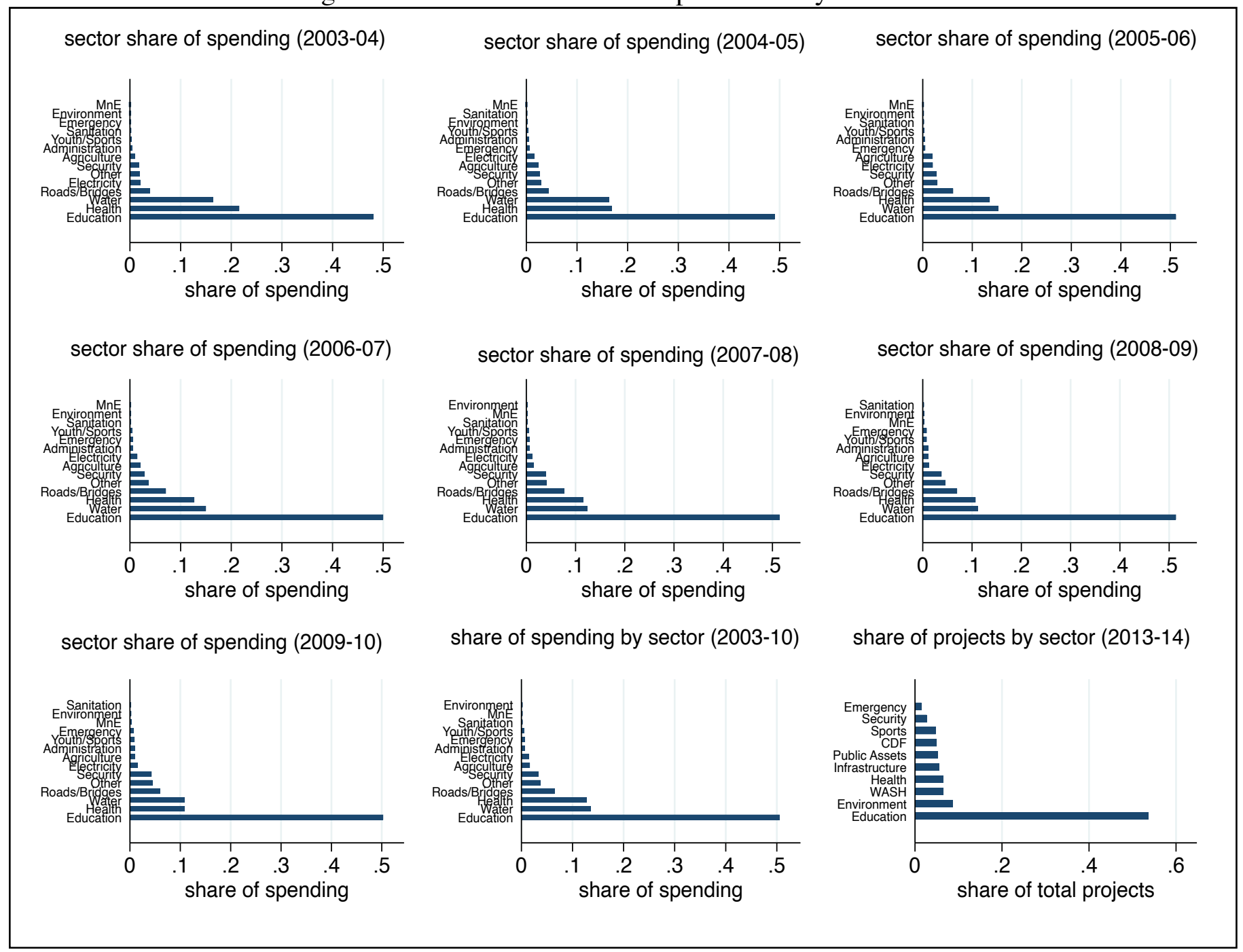

Notes: Figures indicate CDF expenditures by sector between 2003-2010 and in 2013-14. Notice the consistently high expenditures on education. Figures in the education sector include both school construction and bursary allocations. Data from the CDF/NG-CDF Board.

Overall, the actual distribution of CDF projects largely mirrors respondents' revealed priorities. This, and the relative stability of the distribution of sectoral investments by politicians over decades, are indicative of the temporal stability of the logics behind constituency service in Kenya. Instead of being ad hoc forms of clientelism, these investments follow historically established patterns of voter demands and responses from their elected representatives. 


\subsection{Correlates of How Voters Evaluate Legislators}

Having shown that voters' stated expectations of elected legislators and sector priorities match observable CDF projects, this section uses survey data to explore the correlates of voters' evaluations of legislative incumbents. I first examine the correlates of respondent's intention to reelect their incumbent - an indicator of levels of satisfaction with incumbents' performance. Second, I restrict the analysis to respondents that voted for the incumbent in 2017 and explore the correlates of the intention to reelect the incumbent legislator. The underlying assumption in these analyses is that voters' intention to reelect incumbents is driven by observed effort, especially regarding constituency service. ${ }^{41}$

Table 2 shows the results of logit regressions, with the stated intention of reelecting the incumbent legislator as the dependent variable. Constituency service in the form of CDF projects is positively correlated with stated reelection of voting for the incumbent legislator, as is the rating of the incumbent. These findings are robust to controlling for respondents' age, sex, education attainment, area of residence, levels of political knowledge, regional fixed effects, and postestimation tests of correlation. Citizen prioritization of formal functions over constituency service is not statistically correlated with the intention to reelect incumbents. These findings suggest that the electoral relationship between Kenyan voters and legislative candidates turn on constituency service - as governed by expectations forged through the historical experience with Harambees. Incumbents' investments in visible and attributable development projects in their constituencies are the primary means through which voters evaluate their effort and responsiveness.

\footnotetext{
${ }^{41}$ Appendix $\mathrm{C}$ provides robustness checks. All results are stable to different specifications and tests.
} 
Table 2: Correlates of Supporting Incumbent Legislators' Reelection

\begin{tabular}{|c|c|c|c|c|}
\hline DC: Support MP Reelection. & (1) & $(2)$ & (3) & (4) \\
\hline CDF Improved Conditions & $\begin{array}{c}1.937 * * * \\
(0.185)\end{array}$ & $\begin{array}{c}1.083 * * * \\
(0.207)\end{array}$ & $\begin{array}{c}1.085 * * * \\
(0.232)\end{array}$ & $\begin{array}{c}1.088 * * * \\
(0.232)\end{array}$ \\
\hline MP Rating & & $\begin{array}{c}0.864 * * * \\
(0.0676)\end{array}$ & $\begin{array}{c}0.853 * * * \\
(0.0716)\end{array}$ & $\begin{array}{c}0.852 * * * \\
(0.0714)\end{array}$ \\
\hline Prioritize Formal Functions & & $\begin{array}{c}0.0171 \\
(0.0594)\end{array}$ & $\begin{array}{c}0.0306 \\
(0.0676)\end{array}$ & $\begin{array}{c}0.0372 \\
(0.0625)\end{array}$ \\
\hline Age & & & $\begin{array}{l}0.00135 \\
(0.0033)\end{array}$ & $\begin{array}{c}0.00132 \\
(0.00332)\end{array}$ \\
\hline Female & & & $\begin{array}{c}0.220 \\
(0.121)\end{array}$ & $\begin{array}{c}0.212 \\
(0.120)\end{array}$ \\
\hline Education & & & $\begin{array}{l}-0.0515 \\
(0.0325)\end{array}$ & $\begin{array}{l}-0.0516 \\
(0.0324)\end{array}$ \\
\hline Urban & & & $\begin{array}{l}0.0781 \\
(0.247)\end{array}$ & $\begin{array}{l}0.0752 \\
(0.250)\end{array}$ \\
\hline Political Knowledge & & & & $\begin{array}{l}-0.137 \\
(0.136)\end{array}$ \\
\hline Constant & $\begin{array}{c}-1.573 * * * \\
(0.144)\end{array}$ & $\begin{array}{c}-3.624 * * * \\
(0.251)\end{array}$ & $\begin{array}{c}-3.527 * * * \\
(0.161)\end{array}$ & $\begin{array}{c}-3.468 * * * * \\
(0.178)\end{array}$ \\
\hline $\mathrm{N}$ & 1902 & 1902 & 1846 & 1846 \\
\hline
\end{tabular}

Standard errors in parentheses (clustered by Kenya's 8 former provinces)

$* \mathrm{P}<0.05, * * \mathrm{p}<0.01, * * * \mathrm{p}<0.001$

Notes: Logit regression estimates of the correlates of supporting the reelection of the incumbent legislator. Positive perceptions of the impacts of CDF projects as well as overall rating of incumbents (on a scale of 1-5) are positively correlated with the intention to reelect the incumbent legislator. 
Table 3: Correlates of Souring on the Incumbent Legislator

\begin{tabular}{|c|c|c|c|c|}
\hline DC: Soured on MP & (1) & (2) & (3) & (4) \\
\hline CDF Improved Conditions & $\begin{array}{c}-1.928 * * * \\
(0.184)\end{array}$ & $\begin{array}{c}-1.085 * * * \\
(0.213)\end{array}$ & $\begin{array}{c}-1.080 * * * \\
(0.233)\end{array}$ & $\begin{array}{c}-1.081 * * * \\
(0.232)\end{array}$ \\
\hline MP Rating & & $\begin{array}{c}-0.871 * * * \\
(0.0992)\end{array}$ & $\begin{array}{c}-0.869 * * * \\
(0.101)\end{array}$ & $\begin{array}{c}-0.868 * * * \\
(0.101)\end{array}$ \\
\hline Prioritize Formal Functions & & $\begin{array}{c}0.0656 \\
(0.0373)\end{array}$ & $\begin{array}{c}0.0471 \\
(0.0366)\end{array}$ & $\begin{array}{c}0.0448 \\
(0.0339)\end{array}$ \\
\hline Age & & & $\begin{array}{l}-0.00120 \\
(0.00289)\end{array}$ & $\begin{array}{c}-0.00122 \\
(0.00289)\end{array}$ \\
\hline Female & & & $\begin{array}{l}-0.170 \\
(0.189)\end{array}$ & $\begin{array}{l}-0.168 \\
(0.185)\end{array}$ \\
\hline Education Attainment & & & $\begin{array}{c}0.0583 \\
(0.0327)\end{array}$ & $\begin{array}{c}0.0579 \\
(0.0336)\end{array}$ \\
\hline Urban & & & $\begin{array}{l}-0.147 \\
(0.244)\end{array}$ & $\begin{array}{l}-0.147 \\
(0.246)\end{array}$ \\
\hline Political Knowledge & & & & $\begin{array}{l}0.0536 \\
(0.155)\end{array}$ \\
\hline Constant & $\begin{array}{c}1.408 * * * \\
(0.137)\end{array}$ & $\begin{array}{c}3.493 * * * \\
(0.275)\end{array}$ & $\begin{array}{c}3.386 * * * \\
(0.121)\end{array}$ & $\begin{array}{c}3.368 * * * \\
(0.120)\end{array}$ \\
\hline $\mathrm{N}$ & 1471 & 1471 & 1426 & 1426 \\
\hline
\end{tabular}

Standard errors in parentheses (clustered by Kenya's 8 former provinces)

$* \mathrm{P}<0.05, * * \mathrm{p}<0.01, * * * \mathrm{p}<0.001$

Notes: Logit regression estimates of the correlates of souring on the incumbent legislator. Positive perceptions of the impacts of CDF projects as well as overall rating of incumbents (on a scale of 1-5) are negatively correlated with the likelihood of reporting not intending to vote for the incumbent, conditional on having voted for them in 2017.

Kenyan legislators face an entrenched incumbency disadvantage (Opalo, 2019). To understand how constituency service contributes to this pattern, I restrict the analysis to a sample of respondents who voted for incumbent legislators, and then analyze the correlates of switching away from the incumbent. Table 3 shows the results on the correlates of souring on the incumbent legislator, having voted for them in 2017. Results show that perceptions of the impact of CDF as 
well as overall ratings of incumbents are negatively correlated with the likelihood of souring on incumbent legislators. This finding is important. The established exchange relationship between Kenyan voters and politicians follows a clear pattern that goes back decades, and which consists of a specific bundle of visible and attributable investments in "development." These investments, in turn, drive incumbents' political fortunes by influencing public opinion on their performance.

\section{Conclusion}

This article argues that, by shaping expectations of what politicians (can) do, historical experiences structure political exchange relationships between voters and politicians. In the specific case of legislators, politicians' capacity to deliver on campaign promises is shaped by the prevailing levels of legislative strength, the nature of the party system, and the states' fiscal and bureaucratic capacity. Given this reality, candidates in legislative elections cannot unilaterally choose the types of campaign promises they pitch to voters. Ceteris paribus, high levels of state capacity and legislatures' ability to influence executive agencies through legislation and oversight are conducive to programmatic politics, while the obverse conditions render targeted clientelism the most credible currency in the political market.

The article also shows that rising costs of clientelism may force change in the direction of programmatic politics. However, such change is seldom discontinuous, but instead yields a layering of formalized forms of constituency service atop a clientelistic base. Persistent voter expectations and shared mental models of what "politicians do" usually define the bounds of feasible reforms of the political market. 
To support these claims, I present evidence on Kenya's Harambee Movement and Constituency Development Fund (CDF). The Harambee Movement was clientelistic, forced candidates in legislative elections to spend personal resources on local development projects, and shaped the political market. In 2003, legislators passed the CDF Act which, building on the legacy of Harambee, provided legislators with public funds for local development and constituency service. In many ways, the CDF was an attempt to formalize the Harambee Movement. Survey data show Kenyan voters' lasting preferences for legislators' constituency service roles (via CDF) over their formal functions in the legislature. At the same time, legislators' project choices largely mirror patterns of voters' demands revealed in surveys. Finally, perceptions of legislators' performance are primarily driven by voters' evaluations of their management of CDF resources. Qualitative evidence going back to the 1960s show remarkable stability in patterns of project choice under both the Harambee Movement and in the CDF era.

While focused on a case study of Kenya, the findings herein have implications for our understanding of clientelism in other contexts. In this regard this paper provides two important takeaways that should inspire future research. First, clientelistic practices such as "vote buying" are not a matter of personal attitudes or unilateral discretion on the part of voters and politicians. Instead, the persistence of clientelism is often due to structural conditions that make it the most credible currency in the political market. Second, societies can implement reforms to reduce the negative impacts of clientelistic politics. However, such reforms are more likely to involve formalization and legitimation of clientelistic practices rather than discontinuous abandonment. 


\section{References}

Aragonés, Enriqueta, Thomas Palfrey and Andrew Postlewaite. 2007. "Political Reputations and Campaign Promises.” Journal of European Economic Association 5(4):846-884.

Ariga, Kenichi. 2010. Entrenched Incumbents, Irresponsible Parties $\mathrm{PhD}$ thesis University of Michigan Ann Arbor, MI

Arriola, Leonardo R. 2013. Multiethnic Coalitions in Africa: Business Financing of Opposition Election Campaigns. Cambridge, UK: Cambridge University Press.

Bagaka, Obuya. 2010. "An Institutionalized View of the Creation of the Constituency Development Fund in Kenya," Kenya Studies Review, Vol. 1, No. 2 pp. 7-19

Banful, Afua. B. 2011. "Do formula-based intergovernmental transfer mechanisms eliminate politically motivated targeting? Evidence from Ghana," Journal of Development Economics, Vol. 96, No. 2, pp. 380-390.

Barkan, Joel D. 1976. “A Reassessment of Conventional Wisdom About the Informed Public: Commne: Further Reassessment of the "Conventional Wisdom:" Political Knowledge and Voting Behavior in Rural Kenya." American Political Science Review 70(2):452-455.

Barkan, Joel D. 1979. "Bringing home the pork: Legislator behavior, rural development and political change in east Africa." In Legislatures in Development, ed. J. Smith and L. Musolf. Durham, NC: Duke University Press.

Barkan, Joel D. and John Okumu. 1980.” Linkage without parties: Legislatures and Constituents in Kenya." In Political Parties Without Linkage: A Comparative Perspective, ed. Kay Lawson. New Haven, CT: Yale University Press pp. 123-146.

Barkan, Joel D. and Michael Chege. 1989. "Decentralizing the State: District Focus and the Politics of Reallocation in Kenya." Journal of Modern African Studies 27(3):431-453.

Ben-Dor, Gabriel. 1974. "Corruption, Institutionalization, and Political Development: The Revisionist Theses Revisited." Comparative Political Studies 7(1):63-83.

Berman, Bruce J., Jill Cottrell and Yash Pal Ghai. 2009. "Patrons, Clients, and Constitutions: Ethnic Politics and Political Reform in Kenya." Canadian Journal of African Studies 43(3):462506.

Bradshaw, York W. 1993. "State Limitations, Self-Help Secondary Schooling, and Development in Kenya.” Social Forces 72(2):347-378.

Bussell, Jennifer. 2019. Clients and Constituents: Political Responsiveness in Patronage Democracies. New York, NY: Oxford University Press. 
Calvo, Ernesto and Maria Victoria Murillo. 2004. "Who delivers? Partisan Clients in the argentine electoral Market." American Journal of Political Science 48(4):742-757.

Cheeseman, Nic, Gabrielle Lynch, and Justin Willis. 2021. The Moral Economy of Elections in Africa: Democracy, Voting and Virtue, Cambridge, UK: Cambridge University Press

Cox, Gary W. 1987. The Efficient Secret: The Cabinet and the Development of Political Parties in Victorian England. Cambridge, UK: Cambridge University Press.

Cox, Gary W. and Mathew D. McCubbins. 1993. Legislative Leviathan: Party Government in the House. Berkeley, CA: University of California Press.

Dasgupta, Aditya and Devesh Kapur. forthcoming. "The Political Economy of Bureaucratic Overload: Evidence from Rural Development Officials in India." American Political Science Review

Erikson, Robert S. 1971. "The Advantage of Incumbency in Congressional Elections." Polity 3(3):395-405.

Fenno, Richard F. 1978. Home Style: House Members in Their Districts. Boston, MA: Little, Brown.

Ferejohn, John. 1974. Pork Barrel Politics: Rivers and Harbors Legislation, 1947-1968. Stanford, CA: Stanford University Press.

Gadjanova, Elena. 2017. "Electoral clientelism as status affirmation in Africa: evidence from Ghana." Journal of Modern African Studies 55(4):593-621.

Golden, Miriam and Brian Min. 2012. "Distributive Politics Around the World." Annual Review of Political Science 16:73-99.

Harris, J. Andrew and Daniel N. Posner. 2019. “(Under What Conditions) Do Politicians Reward Their Supporters? Evidence from Kenya's Constituency Development Fund.” American Political Science Review 113(1):123-139.

Harris, Kirk A. 2021. ““A A Leader Is Associated with Development”: Kenya's Constituency Development Fund in Historical Perspective." Africa Today 68(1):23-46.

Hicken, Allen. 2011. "Clientelism.” Annual Review of Political Science 14:289-310. Huckshorn, Robert J. 1985. "Who Gave It? Who Got It?: The Enforcement of Campaign Finance Laws in the States.” Journal of Politics 47(3):773-789.

Kruks-Wisner, Gabrielle. 2018. "The Pursuit Of Social Welfare: Citizen Claim-Making in Rural India." World Politics 70(1):122-163.

La Raja, Raymond J. 2008. Small Change: Money, Political Parties, and Campaign Finance 
Reform. Ann Arbor, MI: University of Michigan Press.

Leonard, D. 1991. African Successes: Four Public Managers of Kenyan Rural Development. Los Angeles, CA: University of California Press.

Lindberg, Steffan I. 2010. "What Accountability Pressures do MPs in Africa Face and How do they Respond? Evidence from Ghana." Journal of Modern African Studies 48(1):117-142.

MacDonald, Jason A. and Robert J. McGrath. 2016. "Retrospective Congressional Over- sight and the Dynamics of Legislative Influence over the Bureaucracy." Legislative Studies Quarterly 41(4):899-934.

Mahoney, James and Kathleen Thelen, eds. 2010. Explaining Institutional Change: Ambiguity, Agency, and Power. Cambridge, UK: Cambridge University Press.

Mani, Anandi and Sharun Mukand. 2007. "Democracy, Visibility and Public Good Provision." Journal of Development Economics 83:506-529.

Mbithi, Philip and Rasmus Rasmusson. 1977. Self Reliance in Kenya: The Case of Harambee. Uppsala, Sweden: Scandinavian Institute of African Studies.

Molina, Jose. 2001. "The Electoral Effect of Underdevelopment: Government Turnover and its Causes in Latin American, Caribbean and Industrialized Countries." Electoral Studies 20:427446.

Morgan, Kimberly J. 2013. "Path Shifting of the Welfare State: Electoral Competition and the Expansion of Work-Family Policies in Western Europe.” World Politics 65(1):73-115.

Mwangi, Oscar Gakuo. 2008. "Political Corruption, Party Financing and Democracy in Kenya." Journal of Modern African Studies 46(2):267-285.

Mwiria, Kilemi. 1990. "Kenya's Harambee Secondary School Movement: The Contradictions of Public Policy." Comparative Education Review 34(3):350-368.

Ngau, Peter M. 1987. "Tensions in Empowerment: The Experience of the Harambee Movement in Kenya." Economic Development and Cultural Change 35(3):523-538.

Nichter, Simeon. 2018. Votes for Survival: Relational Clientelism in Latin America. Cambridge, MA: Cambridge University Press.

Opalo, Ken Ochieng'. 2019. Legislative Development in Africa: Politics and Postcolonial Legacies. Cambridge, UK: Cambridge University Press.

Opalo, Ken Ochieng'. 2020a. "Citizen Political Knowledge and Accountability: Survey Evidence on Devolution in Kenya." Governance 33(4):849-869. 
Opalo, Ken Ochieng'. 2020b. "Constrained Presidential Power in Africa? Legislative Independence and Executive Rule Making in Kenya, 1963-2013.” British Journal of Political Science 50(4):1341-1358.

Opalo, Ken Ochieng'. 2021. "Leveraging legislative power: distributive politics and Commit- tee work in Kenya's National Assembly." Journal of Legislative Studies

Singer, Matthew and Ryan Carlin. 2013. "Context Counts: Election Cycle, Development, and the Nature of Economic Voting," Journal of Politics, Vol. 74, No. 3 pp. 730-742

Stokes, Susan C. 2005. "Perverse Accountability: A Formal Model of Machine Politics with Evidence from Argentina." American Political Science Review 99(3):315-325.

Stokes, Susan C., Thad Dunning, Marcelo Nazareno and Valeria Brusco. 2013. Brokers, Voters, and Clientelism: The Puzzle of Distributive Politics. Cambridge, UK: Cambridge University Press.

Thelen, Kathleen. 2004. How Institutions Evolve: The Political Economy of Skills in Ge many, Britain, the United States and Japan. New York, NY: Cambridge University Press.

Thomas, Barbara P. 1987. "Development Through Harambee: Who Wins and Who Loses? Rural Self-help Projects in Kenya." World Development 15(4):463-481.

Transparency International. 2001. Harambee: Pulling Together or Pulling Apart? Technical report Transparency International - Kenya and The Friedrich Ebert Stiftung Nairobi, Kenya: .

Tromborg, Mathias W. and Leslie A. Schwindt-Bayer. 2018. "Constituent Demand and DistrictFocused Legislative Representation.” Legislative Studies Quarterly 44(1):35-64.

Tsubura, Machiko. 2013. "The Politics of Constituency Development Funds (CDFs) in Comparative Perspective." APSA 2013 Annual Meeting Paper.

Uppal, Yogesh. 2009. “The Disadvantaged Incumbents: Estimating Incumbency Effects in Indian State Legislatures.” Public Choice 139:9-27.

Waiguru, Anne. 2006. "Corruption and Patronage Politics: Harambee in Kenya." In Measuring Corruption, ed. Charles Sampford, Arthur Shacklock, Carmel Connors and Fredrik Galtung. Law, Ethics and Governance Series Ashgate Publishing chapter 13.

Wantchekon, Leonard. 2003. "Clientilism and Voting Behavior: Evidence from a Field Experiment in Benin.” World Politics 55(3):399-422.

Williams, Martin. 2017. "The Political Economy of Unfinished Development Projects: Corruption, Clientelism or Collective Choice?” American Political Science Review 111(4):705- 723.

Winans, Edgar V. and Angelique Haugerud. 1977. "Rural Self-Help in Kenya: The Harambee Movement.” Human Organization 36(4):334-351. 


\section{Formalizing Clientelism in Kenya: From Harambee to the Constituency Development Fund}

December 8, 2021

\section{A Additional Information About the CDF}

Throughout this paper I refer to the NG-CDF simply as CDF. The CDF Act was passed in Parliament in 2003 under the National Rainbow Coalition (NARC) administration. NARC defeated the Kenya African National Union (KANU), the party in power since independence, in the 2002 General Election. With the demise of KANU came significant improvements in the legislature's organizational capacity and powers vis-à-vis the president. ${ }^{1}$ Before the passage of the CDF Bill, the government set up a the Task Force on Public Collections or "Harambees," headed by Hon. Koigi wa Wamwere, a Member of Parliament. ${ }^{2}$

The task force investigated the origins and impacts of Harambees and their linkages to corruption. It also sought to find a way of "institutionalizing philanthropy, charities, and endowment funds in Kenya." Overall, the both the government and Civil Society organizations were keen to rein in the Harambee movement as it had been linked to corruption in the public sector under the previous administration of Daniel arap Moi (1978-2002). ${ }^{3}$ In addition, the Harambee movement empowered the president vis-á-vis legislators - the president sat atop patronage networks that financed Harambees and controlled the public bureaucracy that issued Harambee permits under the Public Collections Act. ${ }^{4}$. These tools enabled the president, through the ruling, to make and unmake the political careers of legislators. ${ }^{5}$

\footnotetext{
${ }^{1}$ See Opalo, Ken Ochieng'. 2019. Legislative Development in Africa: Politics and Post-Colonial Legacies. Cambridge, UK: Cambridge University Press.

${ }^{2}$ Kenya Government Gazette, No 45 April 17, 2013

${ }^{3}$ See Transparency International. 2001. Harambee: Pulling Together or Pulling Apart? Technical report Transparency International - Kenya and The Friedrich Ebert Stiftung Nairobi, Kenya

${ }^{4}$ Public Collections Act, 1960

${ }^{5}$ Kanyinga, Karuti. "Messy Politics - the Legacy of Moi's Rule," Daily Nation, March 18, 2020
} 
In 2015 the National Assembly created the NG-CDF following a successful challenge to the constitutionality of the CDF (which was deemed to have usurped an executive function). ${ }^{6}$ The NG-CDF operates much in the same way as its predecessor, with a few modifications. While previously the board was directly answerable to parliament, after 2015 the NG-CDF was domiciled in the executive branch (Treasury and Planning) in order to give it a veneer of separation of powers. Despite this institutional accommodation, the legislature still retains substantial control over the board and its activities. The board reports directly to parliament. At the constituency level, CDF committees are charged with identifying projects and seeing their implementation (again, under the heavy influence of legislators). These committees comprise, the national government official responsible for co-ordination of national government functions; two men one of whom should be a youth at the date of appointment; two women, one of whom should be a youth at the date of appointment; one persons with disability nominated by a registered group representing persons with disabilities in the constituency; two persons nominated by the constituency office established under Regulations made pursuant to the Parliamentary Service Act; the officer of the Board seconded to the Constituency Committee by the Board who shall be an ex officio member without a vote; andone member co-opted by the Board in accordance with Regulations made by the Board. ${ }^{7}$

Figure 4 in the main paper shows the distribution of projects between 2003-2014. While more recent disaggregated data on approved expenditures is not readily available, there is data on project proposals - the most recent being the 2020/2021 fiscal year proposals. Figure A1 shows the distribution of expenditures by sector for 2583 projects from a sample of 41 constituencies (out of 290) selected from counties in all the 8 former provinces in Kenya Central (Nyeri), Coast (Taita Taveta), Eastern (Machakos), Nairobi (Nairobi), North Eastern (Wajir), Nyanza (Siaya), Rift Valley (Uasin Gishu), and Western (Vihiga). The data confirms the wider pattern of education being far and away the most important expenditure. This is

\footnotetext{
${ }^{6}$ See "Court declares CDF Act invalid, gives govt 12 months to make amendments" Daily Nation, February 20,2015

${ }^{7}$ National Government Constituencies Development Fund Act (no. 30) 2015.
} 
partially a reflection of the Harambee legacy. ${ }^{8}$

Figure A1: Sectoral Distribution of Expenditures (CDF 2020/2021 Proposals)

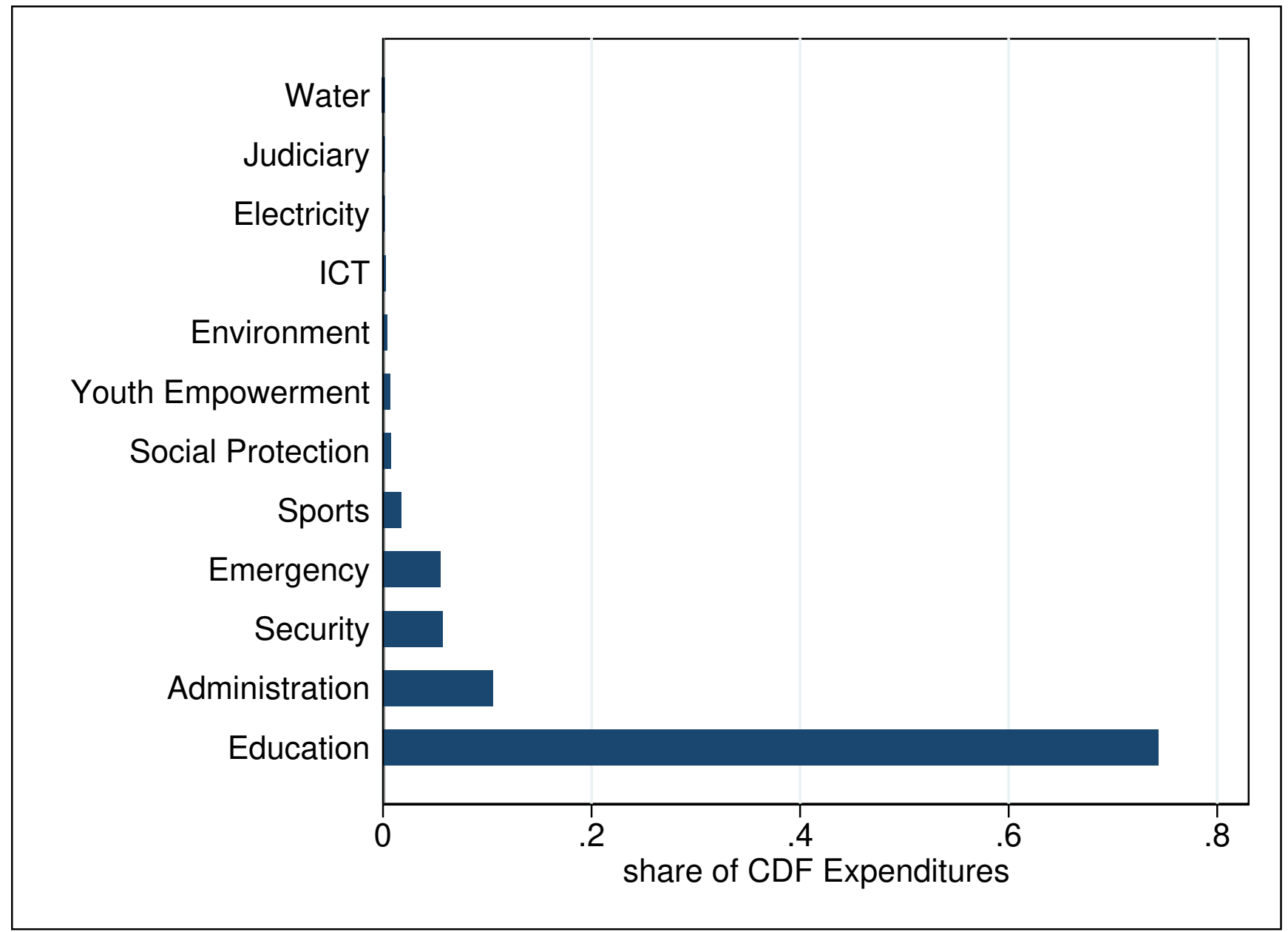

Notes: Figures show the expenditure share distribution across different sectors for a sample $(\mathrm{N}=2583)$ submitted to the NG-CDF. Education is far and away the most important sector.

The enduring political significance of Harambees was demonstrated by the fact that, after instituting the CDF, legislators also sought to insulate themselves against deep-pocketed challengers by banning Harambees within eight months of elections. ${ }^{9}$ As show in Figure A2, legislators are often keen to advertise their use of CDF funds for local development through

\footnotetext{
${ }^{8}$ It is also a reflection of the restriction of CDF expenditures to national government functions under devolution. Education is a national government function. However, devolution cannot explain the findings from before amendments to the CDF Act in 2015 illustrated in the paper. Then, even when legislators could spend on any sector they wanted, they still spent the bulk of their CDF allocations on education.

${ }^{9}$ Article 26 of The Elections Act (2011) states that "A person who directly or indirectly participates in any manner in any or public fundraising or harambee within eight months preceding a general election or during an election period, in any other case, shall be disqualified from contesting in the election held during that election year or election period."
} 
Figure A2: The Ubiquity of CDF Projects in Kenya
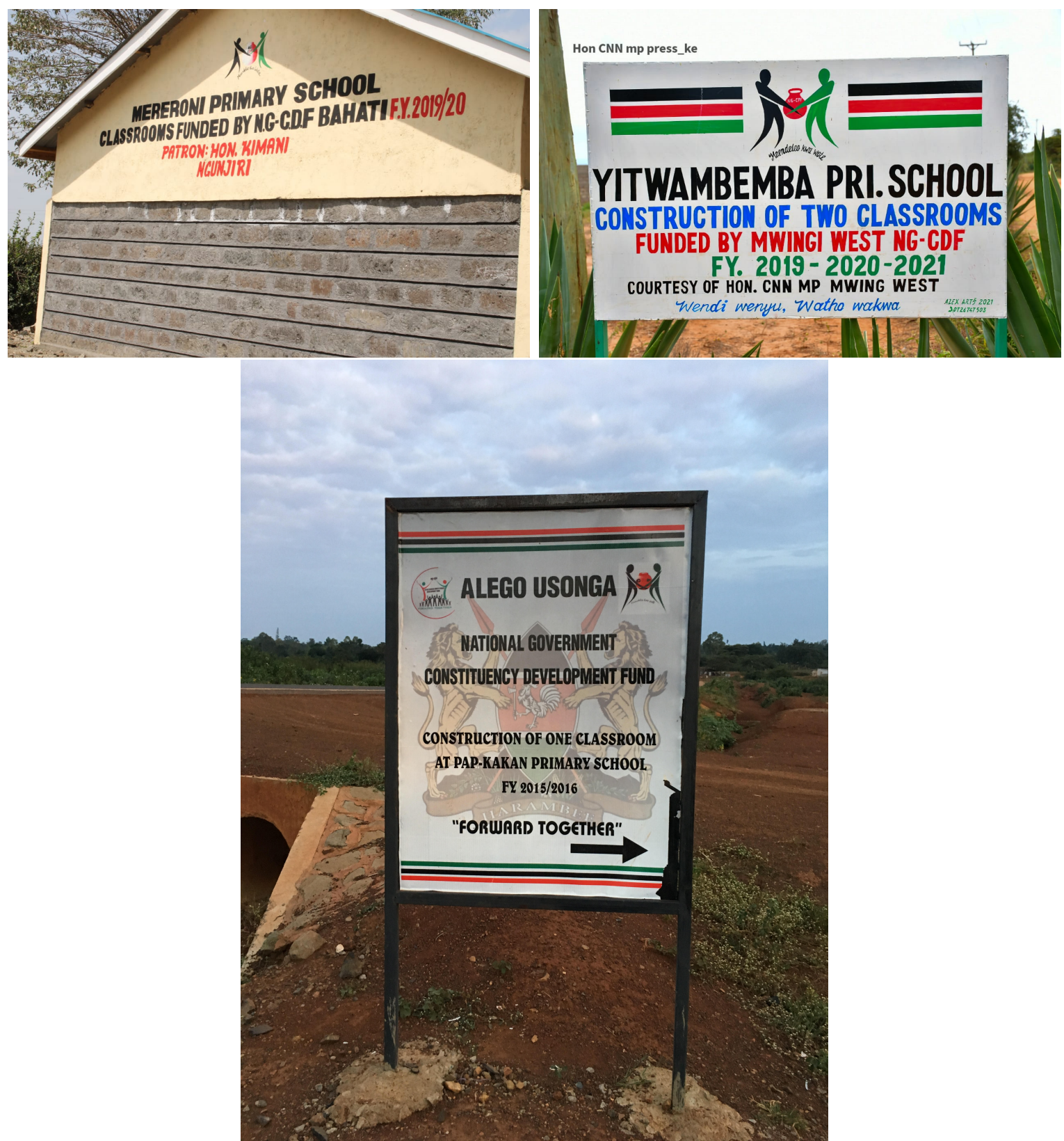

Notes: Figures show signage linking specific projects to legislators' efforts under the NG-CDF in Bahati and Mwingi West constituencies, respectively. Images are from the NG-CDF Board (top two) and the author.

easily visible signage. Civil Society organizations in Kenya routinely rank legislators on the basis of their CDF performance. ${ }^{10}$

In addition to the Harambee System, the importance of candidate-centric politics in

\footnotetext{
10"Kiharu CDF ranked best managed kitty," Daily Nation, June 29, 2020
} 
Kenya has historically been reinforced by the weakness of political parties. Since the reintroduction of multiparty politics in 1992, Kenyan political parties have largely functioned as special purpose vehicles designed for building elite alliances. As result, political parties lacked organizational reach into Kenyan society or associated with important civil society organizations like trade unions. The historical organizational weakness of political parties foreclosed on the possibility of machine politics as a means of mobilizing voters and signaling responsiveness. Therefore, whether or not individual politicians may have preferred machine politics to targeted contributions was immaterial. The structural conditions within the political system put a premium on candidate-centric forms of signaling competence and responsiveness to voters.

Before 2003 legislators had two institutional channels of influencing the allocation of resources to their constituencies. First, they could attend District Development Committee (DDC) and try and influence allocation decisions therein. But as one legislator observed during a CDF debate, legislators lacked the power to compel executive agencies to action using this strategy: "the work of a Member of Parliament has been very frustrating because the constituents expect that he or she would be the one to spearhead development in the constituency. When the Member of Parliament ensures that he attends all the sub-DDC and DDC meetings, all he ends up doing with the rest of those who sit on those committees is that they draw up what they call the annex .. [making recommendations].. and then, the annex is sent to the central Government."11

Second, they could ingratiate themselves to the executive branch and hope that Cabinet Ministers or the president himself would direct resources to their constituencies through agencies in specific line ministries. This, too, was not a good strategy, as it exposed legislators to the whims of the president and Cabinet Ministers. Indeed, for much of his rule, Moi used the threat of rationing "development" as a means of keeping legislators in line. Those that showed any sign of independence were cut off, and therefore doomed to lose elections.

\footnotetext{
${ }^{11}$ foonoteOfficial Report, Kenya National Assembly, October 23, 2003 Col. 2631
} 


\section{B Public Opinion Survey on Legislators and CDF}

The IPSOS Omnibus survey that provided data for this study was conducted in April 2020. The survey was nationally representative and was conducted over the phone with respondents from Central (13.10\%), Coast (8.8\%), Eastern (14.9\%), Nairobi (10.5\%), North Eastern (4.8\%), Nyanza (13.1\%), Rift Valley (24.6\%), and Western (10.2\%) regions. A total of 2000 respondents participated in the survey. The criterion for inclusion in the survey was voter eligibility (Kenyan citizens who are 18 years and older). The survey was conducted in English, Kiswahili, and Somali.

The survey was conducted at the beginning of the COVID-19 pandemic and in the middle of the jostling over the Building Bridges Initiative. However, there is little evidence that the pandemic or alliance politics have altered the underlying dynamics that govern legislative elections in Kenya. Kenya's legislative elections are typically candidate-centric. Furthermore, because the vast majority of constituencies are overwhelmingly dominated by single ethnic groups, ethnicity and associated alliance building strategies will likely have the same historical influences in the 2022 cycle (with candidates switching parties for strategic reasons). Various studies of Kenyan legislative elections have shown results consistent with the survey findings. About $60 \%$ of legislators typically lose their reelection bids. The IPSOS survey shows that only $44 \%$ of respondents would re-elect their MP. The most recent Afrobarometer data (Round 7) shows an MP approval rating of 45.3\%. Therefore, there is no reason to believe that the 2022 presidential election cycle, and the accompanying alliance politics (including the failed BBI initiative) have appreciably shifted the dynamics of legislative politics away from the common trend. For these reasons, there is cause to be confident about the findings from the IPSOS survey.

Q: Important factors driving vote choice in legislative elections: When choosing your member of parliament (to the national assembly), how relevant to you are the following factors? Please rank the choices listed from the most important (1) to least important (5).

- Oversight of national government 
- Making laws in parliament

- Representation in parliament

- Use of CDF (constituency development fund)

- Giving money for constituents' needs

Q: Knowledge of division of labor across different tiers of government: Different leaders in Kenya perform different functions. Which of the following public officials is primarily responsible for providing services related to the following sectors and issue areas? [Options include President, Governor, and MP (National Assembly)]

- Agriculture

- Education

- Electricity

- Healthcare

- Roads

- Water and sanitation

Q: Prioritizing institutional/formal functions vs direct/informal functions: Which of the following statements do you most agree with: MPs should mostly focus on making laws, overseeing the national government, and representing their constituents in the national assembly

OR

MPs should mostly focus on using money from CDF to implement development projects in their constituencies

Q: Impact of CDF: In your opinion, would you say that CDF investments have contributed to the improvement or worsening of development outcomes in your constituency?

- Improved

- Stayed the same

- Worsened

- Don’t Know

- Refused to answer

Q: Rating of MP performance on CDF: Overall, on a scale of 1-5 where 1 is performed poorly and 5 performed very well, how would you rate your MP's performance with regard to the use of CDF funds?

Q: Priority sectors for CDF: In your opinion, which sectors should MPs prioritize when spending CDF resources? Please rank the following sectors from the most priority (1) to least priority (6). 
- Agriculture

- Education

- Electricity

- Healthcare

- Roads

- Water and sanitation

Q: Vote Choice in 2017: In the 2017 general election, did you vote for the current member of parliament? a) Yes b) No c) Don't remember d) Refused to answer

Q: Hypothetical Vote Choice: If elections were held today, would you vote to re-elect the current member of parliament? a) Yes b) No c) Don't remember d) Refused to answer

\section{B.1 IPSOS Survey Summaries}

Figure A3 shows the rankings of different roles of legislators in the IPSOS survey. Use of CDF clearly dominates the other roles in both the First and Second rank category. In short, Kenyan voters prefer constituency service over formal legislative functions.

Figure A4 shows project prioritization across multiple ranks. Education and healthcare dominate the First and Second ranks. The dominance of education matches the historical pattern in Kenya whereby education was the dominant target of Harambee projects. 


\section{Figure A3: Distribution of Reported Top Considerations When Voting}
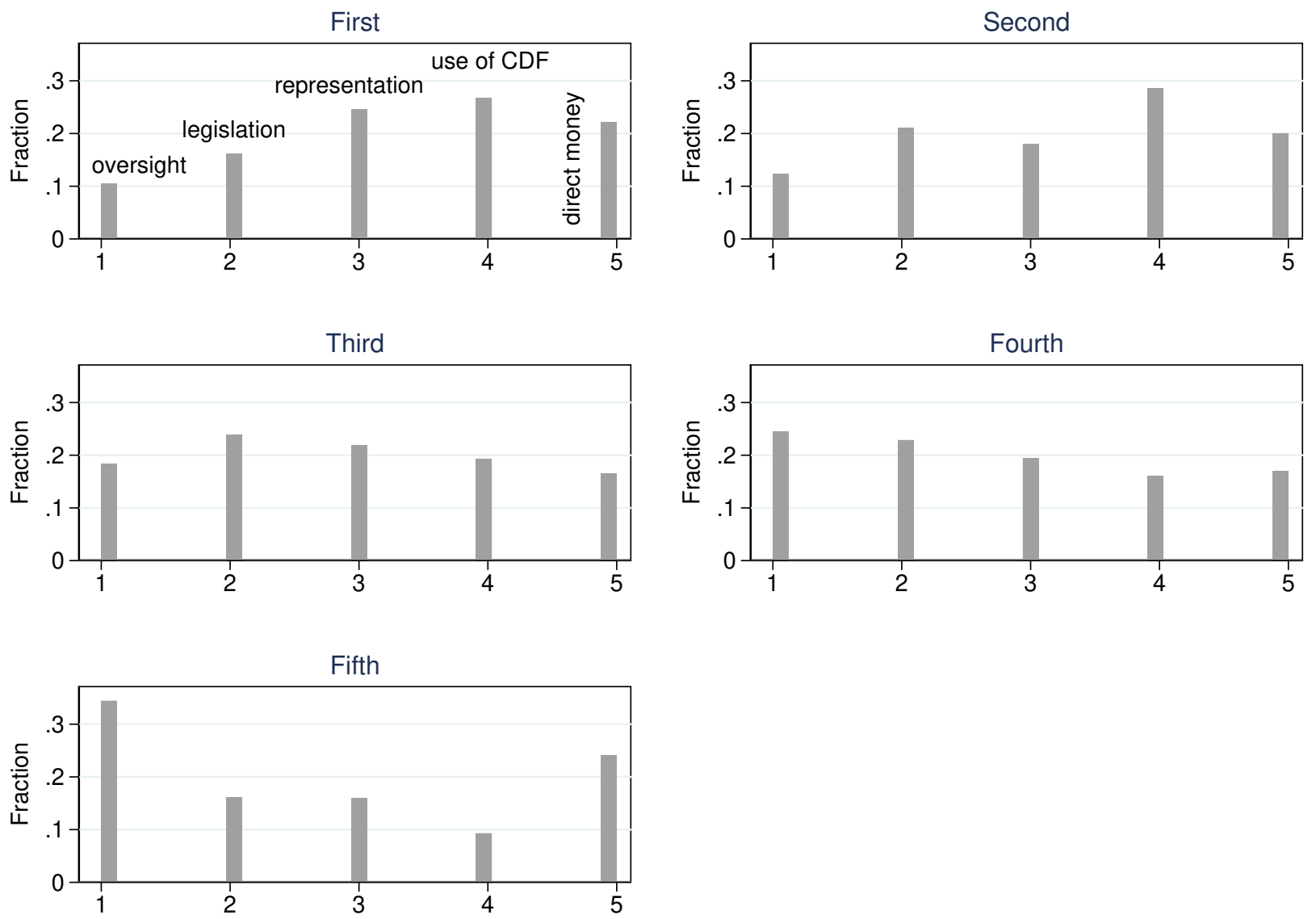

Notes: Figures shows the breakdown of respondent's ranked factors of consideration when voting in legislative elections. 
Figure A4: Distribution of Reported Top Priority Sectors
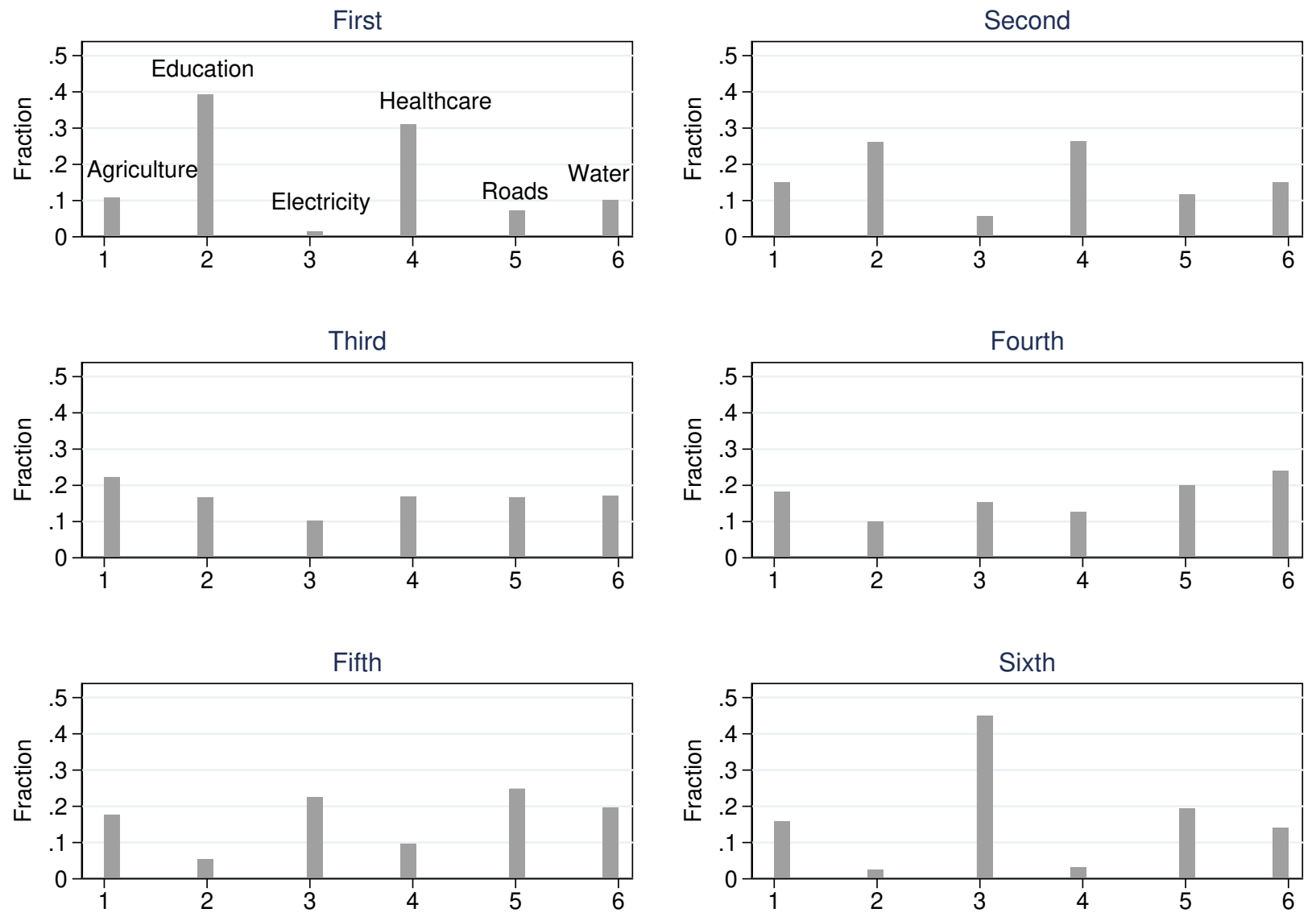

Notes: Figures shows the breakdown of respondent's preferred priority CDF sectors in the nationally- representative IPSOS Survey. 


\section{B.2 Afrobarometer Survey Summaries}

Data from Afrobarometer surveys (Figures A5 and A6) largely confirm the findings in this paper. Most respondents do not consider formal legislative functions to be important; a fact that is reflected in the lack of any statistically significant correlation between prioritizing of formal functions and the approval of legislators' performance. Like in the IPSOS survey, higher levels of education is correlated with a preference for using legislators' formal functions when evaluating their performance in office. However, this is a very small share of the electorate. Overall, the Afrobarometer Survey data is yet more evidence of the tenuous relationship between formal legislative functions and electoral performance - meaning that when legislators enter the political market they cannot afford to use their formal roles (passing laws and oversight) as credible currency.

The rankings of the most important legislative functions in Kenya mirror those in other African countries (Figures A7 and A8). This is not surprising, since most African countries share similar conditions of low state capacity and histories of clientelistic politics that render programmatic campaign promises incredible. This is a call for more research to understand the specific historical conditions driving clientelism in different African countries. Kenya has Harambee and its influence on political culture. Other countries are likely to have their own specific moral political economies that inform their respective political markets. 
Figure A5: Correlates of Valuing Legislators' Formal Functions

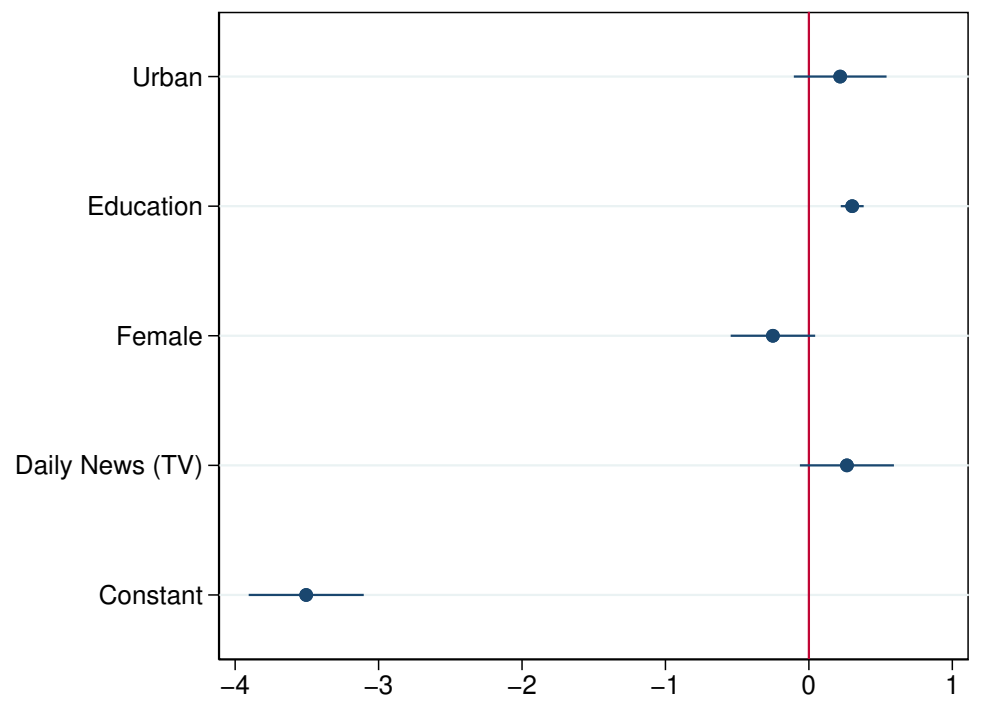

Notes: Figure shows the correlates of considering formal functions of legislators to be their most important roles. Data from Afrobarometer Round 2.

Figure A6: Correlates of Approving Legislators' Performance

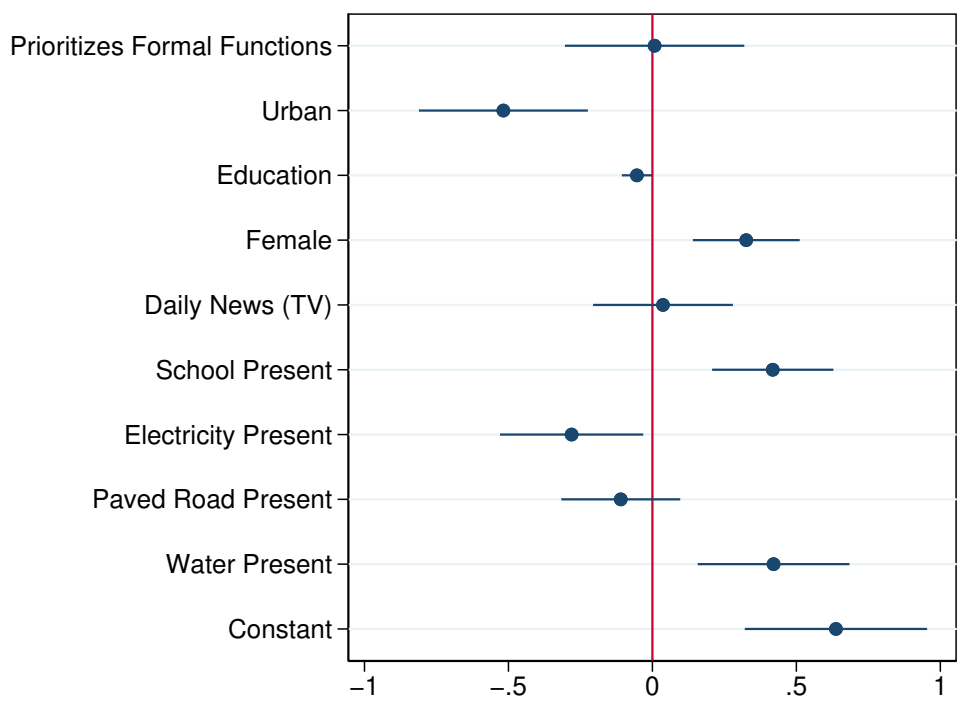

Notes: Figure shows the correlates of positive approval of legislators. Data from Afrobarometer Round 2. 


\section{Figure A7: Views on Most Important MP Functions (Kenya)}

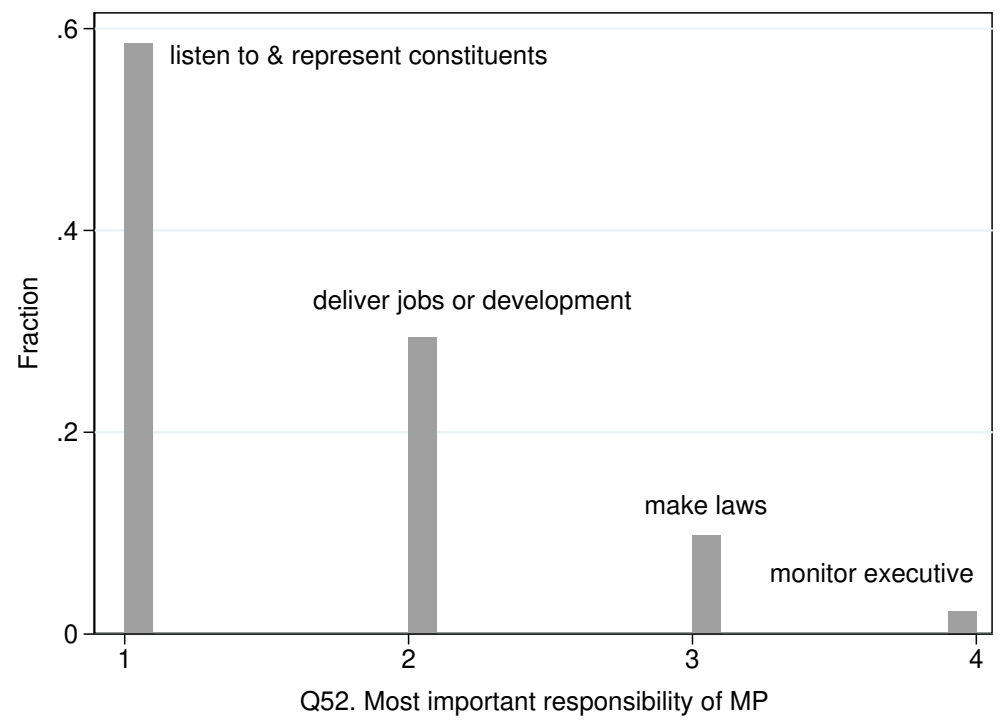

Notes: Figure shows the distribution of views on the most important function of legislators in Kenya. Data from Afrobarometer Round 4.

Figure A8: Views on Most Important MP Functions (Merged, Africa)

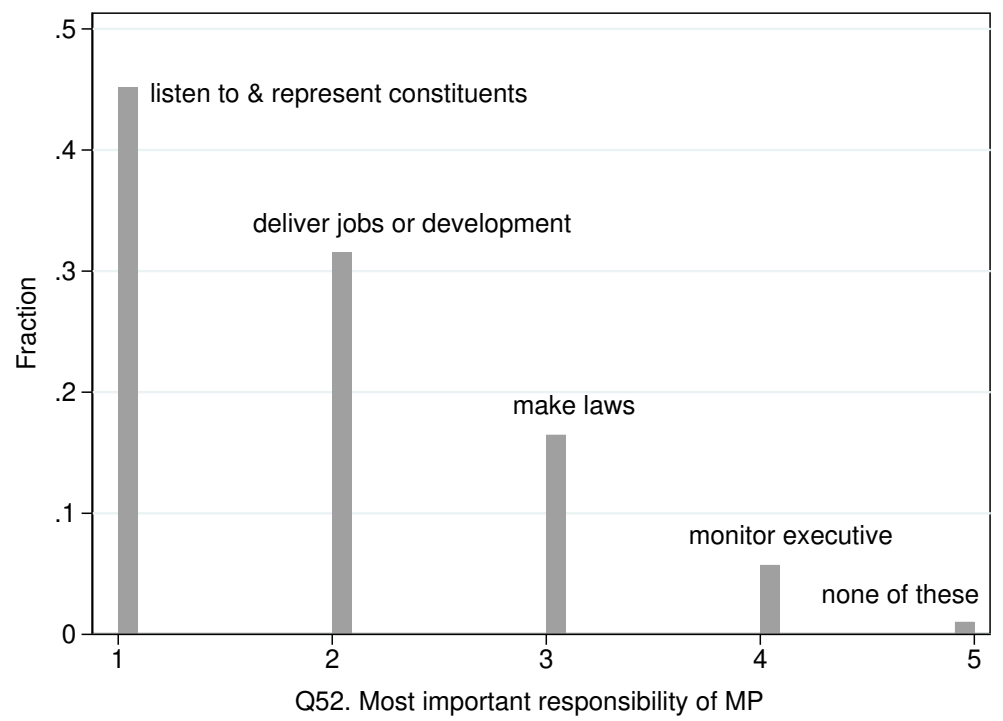

Notes: Figure shows the distribution of views on the most important function of legislators in 20 African states. Data from Afrobarometer Round 4. 
Figure A9: Trends in Approval Ratings of Presidents and Legislators (Rounds 1-7)

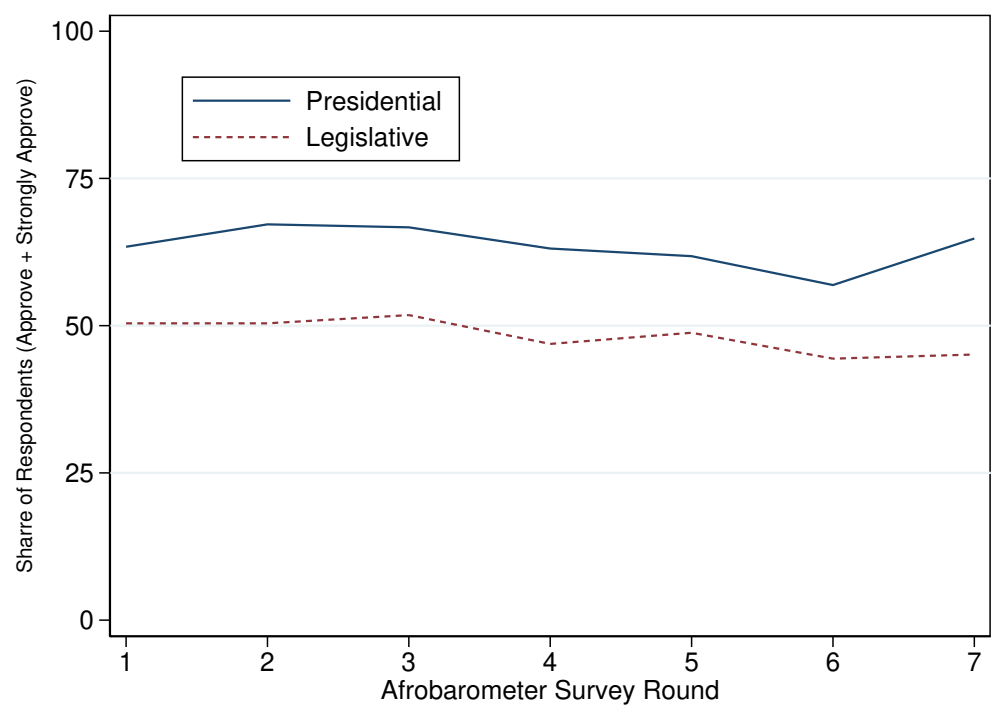

Notes: Figure showing the gap in incumbent approval rating between presidents (solid line) and legislators (dotted line). Across the 7 rounds, presidents bested legislators on average by just over 15 percentage points. 


\section{Regression Estimates}

Tables A1 and A2 show that the regression results do not change with the omission of MP Ratings, which may influence perceptions of performance with CDF independent of actual views about CDF's importance. Tables A3 and A4 show results of tests of correlation (variation inflation factors, VIF) for the models in columns 4 of Tables A1 and A2. A VIF value between 1-5 is evidence of moderate correlation between variables, but not severe enough to interfere with post-estimation inference. The mean VIF in Table A3 is 1.13; and 1.12 in Table A2. To calculate VIF I run OLS models of the main estimations presented in the paper (Tables 2 and 3). As shown in Figures A9 and A10, OLS results are similar to the Logit regressions in the paper. 
Table A1: Correlates of Supporting Incumbent Legislators' Reelection

\begin{tabular}{|c|c|c|c|c|}
\hline & (1) & $(2)$ & (3) & (4) \\
\hline CDF Improved Conditions & $\begin{array}{c}1.937^{* * *} \\
(0.117)\end{array}$ & $\begin{array}{c}1.953^{* * *} \\
(0.121)\end{array}$ & $\begin{array}{c}1.955^{* * *} \\
(0.121)\end{array}$ & $\begin{array}{c}1.973^{* * *} \\
(0.123)\end{array}$ \\
\hline Prioritize Formal Functions & $\begin{array}{c}-0.0372 \\
(0.101)\end{array}$ & $\begin{array}{c}-0.0112 \\
(0.103)\end{array}$ & $\begin{array}{c}-0.00320 \\
(0.104)\end{array}$ & $\begin{array}{c}0.00541 \\
(0.105)\end{array}$ \\
\hline Age & & $\begin{array}{c}0.00540 \\
(0.00423)\end{array}$ & $\begin{array}{c}0.00536 \\
(0.00423)\end{array}$ & $\begin{array}{c}0.00562 \\
(0.00433)\end{array}$ \\
\hline Female & & $\begin{array}{c}0.263^{*} \\
(0.108)\end{array}$ & $\begin{array}{l}0.253^{*} \\
(0.108)\end{array}$ & $\begin{array}{l}0.254^{*} \\
(0.109)\end{array}$ \\
\hline Education & & $\begin{array}{c}-0.0724^{* *} \\
(0.0265)\end{array}$ & $\begin{array}{c}-0.0723^{* *} \\
(0.0265)\end{array}$ & $\begin{array}{c}-0.0751^{* *} \\
(0.0268)\end{array}$ \\
\hline Urban & & $\begin{array}{l}0.0734 \\
(0.111)\end{array}$ & $\begin{array}{l}0.0692 \\
(0.111)\end{array}$ & $\begin{array}{c}-0.0111 \\
(0.127)\end{array}$ \\
\hline Political Knowledge & & & $\begin{array}{l}-0.176 \\
(0.106)\end{array}$ & $\begin{array}{l}-0.198 \\
(0.107)\end{array}$ \\
\hline Constant & $\begin{array}{c}-1.554^{* * *} \\
(0.112)\end{array}$ & $\begin{array}{c}-1.584^{* * *} \\
(0.272)\end{array}$ & $\begin{array}{c}-1.514^{* * *} \\
(0.276)\end{array}$ & $\begin{array}{c}-1.433^{* * *} \\
(0.309)\end{array}$ \\
\hline Regional Controls & $\mathrm{N}$ & $\mathrm{N}$ & $\mathrm{N}$ & $\mathrm{Y}$ \\
\hline$N$ & 1902 & 1846 & 1846 & 1846 \\
\hline
\end{tabular}

Standard errors in parentheses

${ }^{*} p<0.05,{ }^{* *} p<0.01,{ }^{* * *} p<0.001$

Notes: Logit regression estimates of the correlates of supporting the reelection of the incumbent legislator. Perceptions of CDF performance are strongly correlated with likelihood of supporting incumbents' reelection. 
Table A2: Correlates of Souring on Incumbent Legislator

\begin{tabular}{lcccc}
\hline DV: Soured on MP & $(1)$ & $(2)$ & $(3)$ & $(4)$ \\
\hline CDF Improved Conditions & $-1.928^{* * *}$ & $-1.941^{* * *}$ & $-1.942^{* * *}$ & $-1.956^{* * *}$ \\
& $(0.133)$ & $(0.137)$ & $(0.137)$ & $(0.139)$ \\
Prioritize Formal Functions & 0.0552 & 0.0298 & 0.0271 & 0.0243 \\
& $(0.114)$ & $(0.117)$ & $(0.117)$ & $(0.119)$ \\
Age & & -0.00510 & -0.00514 & -0.00640 \\
& & $(0.00482)$ & $(0.00482)$ & $(0.00500)$ \\
Female & & -0.181 & -0.178 & -0.148 \\
& & $(0.121)$ & $(0.121)$ & $(0.134)$ \\
Education & & $0.0665^{*}$ & $0.0658^{*}$ & $0.0703^{*}$ \\
& & $-0.0300)$ & $(0.0300)$ & $(0.0301)$ \\
Urban & & $(0.140$ & -0.139 & -0.00235 \\
& & & $0.125)$ & $(0.144)$ \\
Political Knowledge & & & 0.0685 & 0.0927 \\
& & & $0.119)$ & $(0.121)$ \\
Constant & $1.379^{* * *}$ & $1.423^{* * *}$ & $1.402^{* * *}$ & $1.423^{* * *}$ \\
& $(0.128)$ & $(0.309)$ & $(0.313)$ & $(0.364)$ \\
\hline Regional Controls & $\mathrm{N}$ & $\mathrm{N}$ & $\mathrm{N}$ & $\mathrm{Y}$ \\
$N$ & 1471 & 1426 & 1426 & 1426 \\
\hline
\end{tabular}

Standard errors in parentheses

${ }^{*} p<0.05,{ }^{* *} p<0.01,{ }^{* * *} p<0.001$

Notes: Logit regression estimates of the correlates of souring on the incumbent legislator. Positive perceptions of the impacts of CDF projects as well as the overall rating of incumbents (on a scale of 1-5) are negatively correlated with the likelihood of reporting not intending to vote for the incumbent, conditional on having voted for them in 2017. 
Figure A10: Correlates of Supporting Incumbent Legislators' Reelection

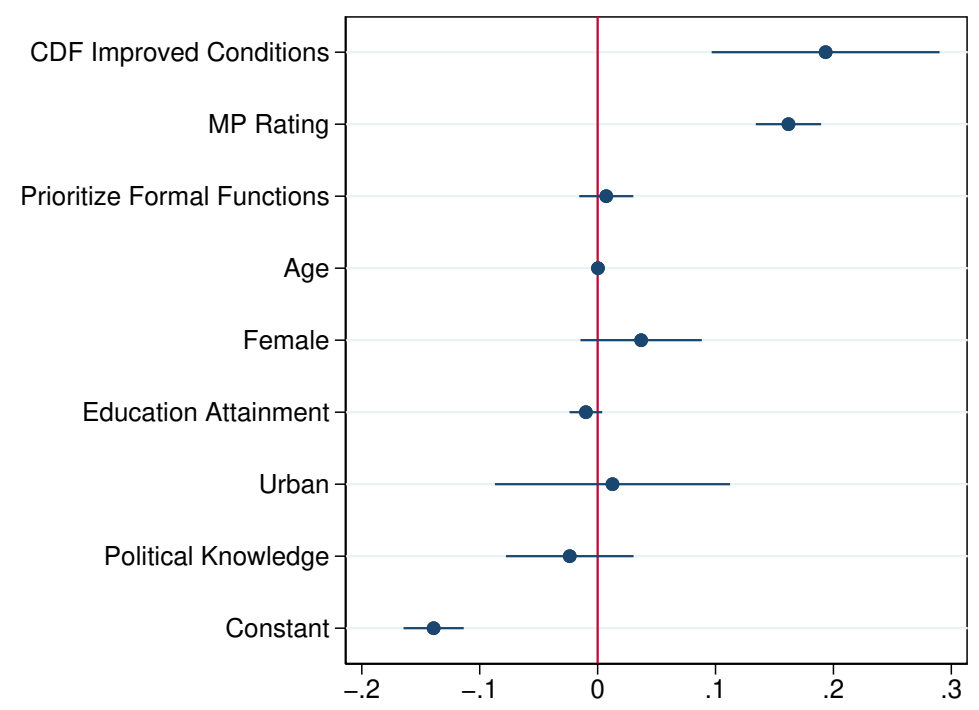

Notes: OLS Notes: Logit regression estimates of the correlates of souring on the incumbent legislator. Positive perceptions of the impacts of CDF projects as well as the overall rating of incumbents (on a scale of 1-5) are negatively correlated with the likelihood of reporting not intending to vote for the incumbent, conditional on having voted for them in 2017.

Figure A11: Correlates of Supporting Incumbent Legislators' Reelection

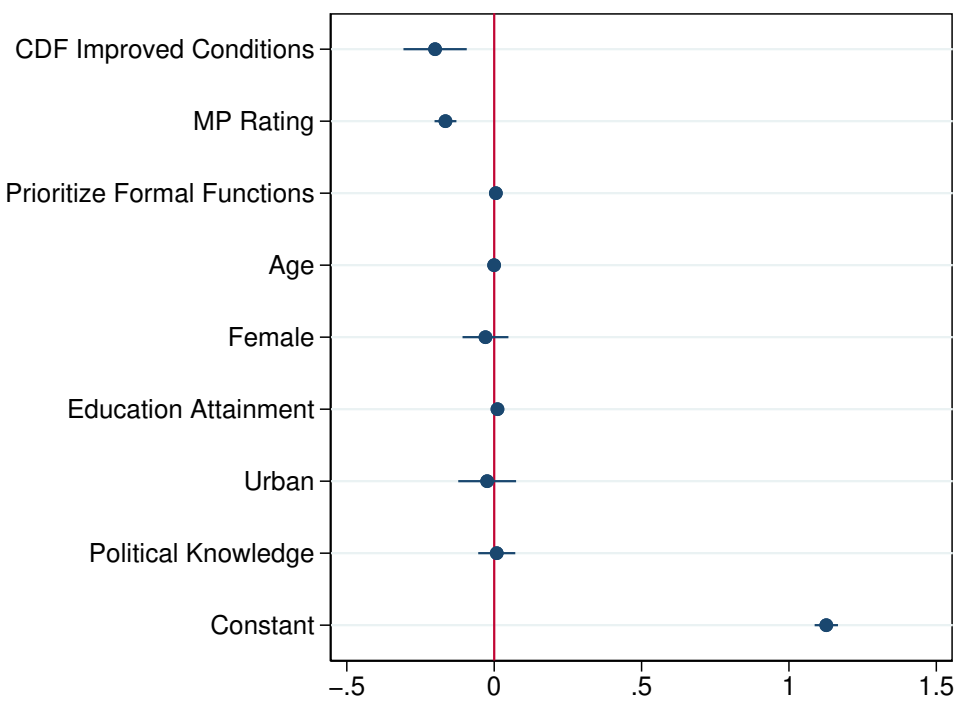

Notes: OLS regression estimates of the correlates of supporting the reelection of the incumbent legislator. Perceptions of CDF performance are strongly correlated with likelihood of supporting incumbents' reelection. 
Table A3: Test of Correlation (Variance Inflation Factor)

\begin{tabular}{l|cc}
\hline Variable & VIF & $1 /$ VIF \\
\hline Rating & 1.35 & 0.742711 \\
CDF Improved Conditions & 1.34 & 0.744507 \\
Education & 1.13 & 0.884238 \\
Age & 1.13 & 0.887789 \\
Female & 1.03 & 0.968661 \\
Prioritize Formal Functions & 1.02 & 0.982814 \\
Political Knowledge & 1.01 & 0.991396 \\
Urban & 1.01 & 0.992233 \\
\hline
\end{tabular}

Table A4: Test of Correlation (Variance Inflation Factor)

\begin{tabular}{l|cc}
\hline Variable & VIF & $1 /$ VIF \\
\hline CDF Improved Conditions & 1.34 & 0.747797 \\
Rating & 1.33 & 0.752573 \\
Education & 1.13 & 0.881889 \\
Age & 1.13 & 0.884341 \\
Female & 1.03 & 0.970163 \\
Prioritize Formal Functions & 1.02 & 0.983995 \\
Urban & 1.01 & 0.986269 \\
Political Knowledge & 1.01 & 0.992380 \\
\hline
\end{tabular}

